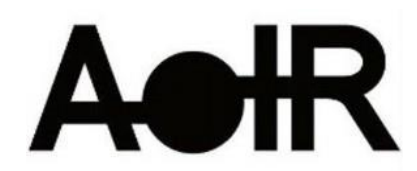

Selected Papers of \#AoIR2020:

The 21 st Annual Conference of the

Association of Internet Researchers

Virtual Event / 27-31 October 2020

\title{
INFORMATION ACTIVISM IN THE FIRST DIGITAL COPYRIGHT DECADE: A CASE STUDY OF THE DIGITAL FUTURE COALITION, 1996-2002 AND THE INTERNET THAT NEARLY WAS
}

\author{
Bryan Bello \\ School of Communication, American University \\ Dr. Patricia Aufderheide \\ School of Communication, American University
}

\begin{abstract}
The Digital Future Coalition (1996-2002) was an unprecedented public interest coalition on Internet and copyright policy with much farther-ranging effects than has been recognized previously. Uniting commercial and noncommercial stakeholders to push back against intellectual property maximalism on the nascent Internet, it altered both treaty and legislative language, entered a trope-"balance"-into national discourse on copyright policy, blocked U.S. copyright protection for databases, enhanced popular engagement with fair use, and set the stage for the "Right to Repair" movement. This historical research was accomplished primarily by interviewing representatives of the Digital Future Coalition (DFC) and opposing groups, as well as one ex-official, and by consulting a hitherto untapped, private archive of documents relevant to the prehistory and 1996-2002 history of the DFC.
\end{abstract}

Keywords: Copyright policy, Internet policy, coalitions, lobbying, Internet history

\section{Introduction}

A public policy coalition in the public interest, the Digital Future Coalition (DFC) played a significant role in a policy process that eventually established the terms of managing copyright on the Internet: the Digital Millennium Copyright Act (DMCA). 1 The creation of the DMCA was a pivotal moment, when the Internet was only beginning to be widely accessible and digital transmission of copyrighted material was still largely ungoverned

Bello, B. \& Aufderheide, P (2020, October). Information Activism in the First Digital Copyright Decade: A Case Study of the Digital Future Coalition, 1996-2002 and the Internet that Nearly Was: The 21th Annual Conference of the Association of Internet Researchers. Virtual Event: AolR. Retrieved from http://spir.aoir.org. 
in practice. One key member of the coalition recalled, "I hope we never see an effort of this magnitude again. Everything was on the table."2

The process of shaping that legislation took four years, beginning in 1994 with a study issued through the Department of Commerce known to participants as the "Green Paper." 3 It argued that the "information superhighway" could never be used without the implementation of draconian copyright protections. The paper was substantially drafted with the help of media company lawyers, especially from Disney.4 It proceeded to be debated as the Green Paper became a White Paper and then, in 1996, a bill in Congress with companion legislation establishing a new "database right." 5 Expeditiously defeated, the bills' proposals became part of the U.S. delegation's negotiations in treaties that emerged at the World Intellectual Property Organization (WIPO) conference in December 1996.6 Action on a database right was stalled, but placeholder agreements on digital copyright were enacted. The Clinton Administration then proposed legislation, ostensibly to conform to the treaties, and later amended it to include database copyright protection; that legislation dueled with counter-legislation. The two bills were debated, lobbied over and amended in 1997-8. The version of the DMCA enacted into law emerged from Congress in October of 1998.7 See Appendix 1 for a timeline.

Among other things, the DMCA created protection from copyright liability for telecommunications entities and the proto-Internet service providers, if their users infringed copyright. In order to win this protection, the service providers or platforms had to take down upon request any offending material; users who countered the takedown were then put in direct contact with the complainant. It also prohibited and criminalized circumvention of encryption (technical protection measures, or TPMs) and creating devices to decrypt, functionally prohibiting otherwise legal forms of sampling and reverse engineering. 8 Finally, it served as a vehicle for advancing an interrelated legislative effort that nearly established a brand-new intellectual property right in collections of digital information, or databases.

This article focuses on the role the DFC played in the first decade of digital intellectual property (IP) legislation, how it worked, and what its legacy is. (See Appendix 3 for a glossary of acronyms.) The DFC played a central role in stopping the first round of domestic digital copyright legislation, in preventing the creation of a U.S. copyright for collections of data, and in significantly modifying U.S. demands at WIPO. It was crucial to altering provisions in the second round of legislation, and its seemingly insignificant independent win in the last hours of legislative negotiation turned out to be the clause that has created the most change in the DMCA over the years. The set of relationships built in the DFC has continued for decades since, as allies worked on similar issues; the DFC brought copyright issues to major nonprofit organizations, and put in motion the processes to start others.

\section{Methods}

We used a well-organized, hitherto untapped archive of documents relevant to the 1993-2002 history of the DFC, archived by the Program on Information Justice and Intellectual Property (PIJIP) at the Washington College of Law. The archive includes 
emails among members, notes from meetings, sign-in sheets, and copies of articles members consulted and produced, as well as leaked information from intellectual property (IP) organizations and copies of versions of legislation. We also interviewed 12 lead actors in the coalition, three representatives from IP maximalist groups, and two people from later organizations, identifying them through sign-in sheets of the DFC, through recommendations from other interviewees, and through consulting existing reports. Finally, we interviewed the public official leading the effort to create the DMCA, Bruce Lehman. Our interview pool prioritized DFC members because their perceptions and understanding of events has been poorly chronicled (as discussed below) in narratives of DMCA policymaking. The views of representatives of IP maximalist groups have, by contrast, been widely shared and used by historians and policy scholars. After analyzing and summarizing our findings we engaged interested interviewees in a member checking process. Respondent validation is an additional way researchers relying on interviews can assess the credibility of their findings.9

We permitted interviewees to retain anonymity if they preferred. If they agreed to be named, we honored a pledge to show them all quotes attributed to them in advance, with the right to remain anonymous on consideration. Although we had obtained an Institutional Review Board (IRB) waiver based on the merits of our pre-submitted questions and outlined interview approach, we believed that such agreements with interviewees would permit franker conversations. We also felt confident in doing so as the rich archive we accessed, which contained leaked documents from DFC's opposition and unedited or curated DFC material, allowed us to further contextualize the statements and reactions of all our interviewees.

\section{Context}

We consider our topic within three context areas: the history of the formation of the DMCA; public interest coalition characteristics in communication; and the political roles of coalitions. Legal and communication scholars have authoritatively tracked the path of the DMCA legislation. 10 In each of these narratives, the DFC plays a role as an ineffective pushback on the unstoppable forces of IP maximalism. For instance, Jessica Litman, who as a fellow worked at the American University law school-a major node in the DFC network - at the height of the DFC, bitterly noted the "failure of the Digital Future Coalition to achieve any concessions of substance" in DMCA negotiations.11 James Boyle, who was also at American University's law school during the DFC's rise, bemoaned the fact that they were defeated because "the currents were running against them," with IP maximalists passionately convinced of their cause even though the DFC represented "a broad range of interested groups." 12 Bill D. Herman's detailed analysis of the diplomatic and legislative process that resulted in the DMCA does feature the DFC, but categorizes it as a nonprofit rather than a coalition of public interest, nonprofit, and industry groups and dismisses it as "really just an umbrella group for other actors, and it was conceived, founded, and run by people who had day jobs other than as full-time policy advocates." 13 In Tarleton Gillespie's Wired Shut, which looks at copyright policy changes with the advent of digital, the DFC receives only a passing mention in descriptions of the DMCA, with no discussion of the coalition's influence.14 In Hector Postigo's discussion of the formation of the DMCA, anti-maximalist and public interest positions are ascribed to individuals and to categories such as librarians but not to 
organizations (the DFC itself is mentioned only in a table listing "digital rights movement organizations, missions statements and classification" at the end of the book).15

The profound and widely recognized consequences of the DMCA's provisions for censorship, limitations on innovation, and regulatory precedent for IP maximalism have been analyzed by many, including the above-mentioned authors.16 They include private censorship through both the takedown process and the anticircumvention provision; the hobbling of digital security research; limiting the ability to repair products independently; and the inhibition of innovation. Here, we accept the assessment of the DMCA as legislation that both foreclosed options for the Internet's development and created an enduring regime to protect copyright monopolies on the Internet. However, we argue that a closer look at the coalition's actions, goals, and long-range effects can reposition that coalition productively in history. Such repositioning helps us understand how different the DMCA today is from the originally proposed policy and the implications of those differences. It also demonstrates that public-interest involvement in policymaking is more than window-dressing or a futile exercise, even given the power dynamics of large corporate interests.

The role of public interest advocates has been explored extensively in the communications area. Mass media and communication public interest advocacy organizations began appearing in the 1970s and grew dramatically in the 1990s.17 The DFC appeared at the height of this growth. But it was distinguished from former advocacy organizations in two ways: it directly addressed the new problem of Internet IP regulation, and its coalition was a mix of nonprofit and for-profit actors. As Napoli charts the history, typically public interest advocacy organizations on communications issues had not worked directly within organizations with commercial interests. 18 Indeed, even academics and activists on a self-described "public interest" continuum (usually featuring some combination of consumer and non-commercial concerns, including concern for future members of the public) have had a difficult time collaborating and routinely construe their interests as opposed to corporate interests. 19 While coalitions on particular issues are typical of advocacy organizations-for instance, the Fairness Doctrine routinely featured "strange bedfellow" combinations including Phyllis Schlafly, the National Rifle Association, and mainline religious organizations-copyright advocacy in the public interest did not have much experience with commercial alliances at the time.20 Just how unusual the DFC's coalition approach was at the time is registered by the reaction of some of the members. Litman argued that the DFC's commercial interests ended up "settling for something that sells the public short" because an over-broad but short piece of legislation, which did not address copyright exceptions, became a tortuously long one with exceptions that are narrower than copyright law generally permits.21 Jamie Love, a public-interest advocate, told us in an interview, "I was not $100 \%$ comfortable; it was portrayed as a nonprofit/for profit coalition, but it was clear to me that the corporate guys were calling a lot of the shots." 22

This work contributes to the literature on media and communications advocacy. Much empirical work on media has focused on movements galvanizing the general publicactivism that is formed from purely nonprofit alliances and around social justice principles, the notion of resistance, and grassroots, participatory, or youth media.23 Much work done on infrastructure policy in communication, by contrast, has focused 
primarily on technological and business interests in policy change;24 this work is well showcased annually, for instance, at the annual Telecommunications Policy Research Conference (tprcweb.com). We strive to contribute to a third area of research: empirical studies of public interest advocacy conducted in complex engagement with the policy process.25 This work is characterized by a focus on movements that engage directly with policymakers and close analyses of the policymaking process, the interactions of different stakeholders, and the public interest stakeholders' influence on the results.

The DFC featured one of the consistent rhetorical frameworks for such public-interest advocacy that Napoli identifies: the freedom to communicate.26 However, unlike a human-rights perspective commonly associated with such a framework, the DFC framed this argument for freedom to communicate within the public and political function of copyright policy. The coalition argued that copyright was designed to be a policy that created incentives to create in a balanced way: both rewarding creative effort with limited monopolies and also rewarding creative effort by permitting limited use of monopoly-protected material in the creation of new culture. Unlike some arguments for balance that assume extremism on both sides and negotiate toward the center-an approach that tends to privilege the powerful-this argument went to the Constitutional grounding of copyright itself: that intellectual property policy exists to promote "Science [i.e. knowledge] and the Useful Arts," and its implementation must use a range of tools, some of which constrain access and others of which enable it. James Madison's Federalist 43 was thus instituted in Article I, section 8 of the Constitution-the so called "progress clause." 27 The constitutionality of the policy is only maintained when there is balance between the different kinds of incentives used. Copyright monopolies must be limited in order to be constitutional; exceptions to monopoly permit the creation of knowledge, too. It was this argument that neatly united the interests of the noncommercial and commercial members of the DFC.

Within scholarly understanding of media and communications public interest efforts, the DFC was thus precedent-setting for a variety of reasons: its members represented both commercial and noncommercial interests at a time when public-interest groups in communication typically eschewed commercial alliances; there had been, until then, no public interest representation on this aspect of Internet policy; the group acted, on minimal funding, with remarkable consensus; and there was a high level of shared respect among coalition members for the core values and principles that shaped the coalition's arguments.

Coalition behaviors, political scientists argue, are governed by reputation, resources, constituencies, and other currencies that can affect action.28 This is a succinct summary of reasons why coalition members sought each other out in the DFC. Stakeholder alliances are expected in political hardball, and they are notoriously transactional, as we know from a well-developed literature on regulatory capture, the "revolving door" between lobbying and government positions, and special interests.29 Coalitions have, however, no clear pattern of success. They have been variously assessed by political scientists as either a dominant force in shaping policy, typically ineffectual or even counter-productive, or conditionally successful. 30 We take from this wild diversity that context-political, social, historical-is crucial to understanding the successes and 
failures of any particular coalition action. This article strives to provide DFC's history within that historically contingent context.

\section{Formation and Interests}

The Green/White papers were part of an aggressive push by the Clinton Administration to re-imagine the American economy in the context of a National Information Infrastructure (NII). 31 Secretary of Commerce Ron Brown headed a special task force appointed by Vice President Al Gore in February 1993. Later that year, the task force published its "Agenda for Action." 32 IP—a top American export-was crucial to the agenda, and so was the proto-Internet, or what was called the "information superhighway." Recalled Bruce Lehman, the then-Commissioner of the U.S. Patent and Trademark Office (USPTO) and self-described true-blue Clintonista: "These intangible property rights were important economic assets to the US economy, and the ability to monetize them was critical to this vision[;] it was the foundation for the economy we envisioned emerging in the 21 st century," 33

From the beginning, commerce was central to the NII, and IP was central to commerce. Thus, the Clinton Administration's decision to place the NII initiative in the hands of the Department of Commerce was an early signal that the Internet would be developed as a commercial network. The Internet up to this point had been defined by experimentation, free discourse, and the creation of culture by early yet robust user communities. The IP Task Force wanted to redirect those patterns of exchange around a legacy rent-seeking framework. Essential to this plan were IP policies appropriate to digital communication. The choice of Lehman to lead the NII's IP Task Force made sense: he had already demonstrated his commitment to IP protection.

The DFC developed when the working group's first publication, the so-called Green Paper, raised concern among Internet users. Where copyright interests saw an opportunity in the proposal put forth-make all internet traffic go through copyright holders - others who benefited from copyright's exceptions and limitations saw a problem. Nonprofit cultural institutions, consumer technology manufacturers and internet service providers were particularly threatened. The nonprofit actors were roused when Pamela Samuelson, a computing-oriented law professor at the University of California Berkeley, read the Green Paper with its stark description of an empty "superhighway" that would remain unused unless the "cars" (intellectual property) on it could travel safely (have copyright protection):

I knew it wasn't close to being an accurate statement of the situation. The notion that the Internet was empty, that nothing is flowing through these empty spaces and tubesI knew lots of people who were using it. But the Green Paper was arguing that in order to induce all the content companies to participate in the new economy, we need these strict rules and anticircumvention. 34

Samuelson immediately thought she understood the implications of tight copyright control over all Internet transmission: it would criminalize most of the then-current Internet activity and stifle future development of the network: 
I realized by looking at some of the journalistic coverage that the journalists couldn't decode the Green Paper. It's full of legalese. One of the things I thought I could do to add value in the world was to explain to the community of computing professionals what these lawyers are talking about. 35

Samuelson began a writing and speaking campaign that for the next few years took her to 25-50 events a year. She wrote in law journals, computing newsletters, and even WIRED magazine.36 In precise prose, she argued that the proposed policy was draconian, stripping citizens of their existing rights to privacy and to the private use of copyrighted materials. It would, she pointed out, criminalize even temporary copies in random-access memory that are critical to basic computer operations. It would, in effect, abolish fair use-the right to reuse copyrighted material under certain circumstanceswhich was a time-honored practice in private life, vital to journalism, and crucial to Internet innovation. It would also do away with first-sale, or the right to do what you will with the IP you bought-a right that enables the very existence of libraries. Furthermore, a proposed database right threatened to fence off the "elementary particles and building blocks of knowledge," or collections of data that were the lifeblood of the nation's scientific communities.37

Samuelson already had experience connecting legal scholarship and constituencies around issues. She previously had done work on software copyright interpretation in the courts, which she found often misunderstood technology and tilted toward extending copyright. Samuelson quickly earned a consulting position with The National Research Council's (NRC) newly established Committee on Data for Science and Technology (CODATA).38 By 1995, she was providing them with briefings on the IP working group's proposed database right and its implications. 39 She and future DFC colleague, legal scholar Jerome Reichman, would prove instrumental in shaping the committee's official position on database IP — they were the most cited scholars in the 1997 CODATA publication on the issue, Bits of Power.40

Independently, law professor Peter Jaszi, an expert on copyright exceptions and limitations, had also seen the Green Paper and was immediately alarmed. "It's an appalling document," he recalled with visceral distaste in 2018.41 Where Samuelson was outraged at the paper's ignorance of existing activity on the Internet, Jaszi was outraged at what he saw as its impingement on free expression and future culture. Holding as his intellectual hero the legal scholar and judge Benjamin Kaplan, Jaszi had built his own scholarly work on the notion of balance between the rights of copyright holders and the rights of users and new creators in the production of culture. 42 In his own work and with others, he had argued that the Romantic notion of authorship itselfcelebrating the unique genius of the creator-was a relatively new social construct, one that had served copyright holders (rarely the creators) for political purposes. 43 For him, copyright holders were not only market actors but potential censors of present and future culture. Fair use was a central concept in balancing copyright, especially as term extensions and other expansionary clauses of copyright policy pushed the balance of power toward copyright holders. "The Green Paper was a redescription of copyright policy," he said. "It described fair use not as a right but as a tax on copyright owners, and prescribed copyright education-'Teach them not to steal.'" 44 
He saw the problem but not a solution, until Samuelson, who was familiar with his work from previous amicus briefs, introduced him to Prue Adler at the Association of Research Libraries (ARL), the most prestigious library association in the U.S. and a gateway organization to the most important research universities in the U.S. and Canada. Samuelson happened to occupy office space at ARL while working with the National Research Council.

Adler was already well aware of the issues. Now the ARL's legislative director, she had come to the organization five years before from the Communications and Information Technologies Program at the (now defunct) Congressional Office of Technology Assessment, a research body on technology policy issues. She knew that libraries in the U.S. exist because of two fundamental balancing features in copyright: first sale and fair use. ARL already had taken action, she recalled:

With the American Library Association, we had hired someone to go through all of that Clinton Administration work so we could identify exactly the areas we understood them to be targeting, where we would need to be involved. We did a set of principles at the same time. Bruce Lehman and the Administration were very clear that they were going to introduce legislation, and it was pretty clear how everybody was lining up. 45

Furthermore, Adler knew how badly the libraries-led by ARL and the American Library Association (ALA) - had fared in the fundamental rewrite of copyright law that resulted in the 1976 Copyright Act. The Act vastly extended copyright monopolies in scope and length. During that legislative battle, librarians had fought hard but lacked commercial allies and largely lost. She welcomed the idea of combining forces and valued Samuelson's business connections. As a result of board members' concerns, she recalled, "in '91 or '92 we brought in people and started working on our agenda. We brought in the ALA. Carol Henderson, who was part of the Washington office of the ALA, had been a part of the [lobbying on the] '76 revision [of the Copyright Act], so we both understood the value of coalition building." 46

Adler and Jaszi called a meeting at American University in Washington, D.C. Samuelson used her industry connections to fill out the guest list. It eventually included representatives from libraries, academia, and consumer electronics and computing companies.47 "Everyone got along quickly and could speak a common language," Adler remembered, noting how unusual it was that an organization was born immediately from the first, one-day meeting. 48

One of the entities with the most clout on the sign-up sheet was the Home Recording Rights Coalition (HRRC) - an industry consortium formed in 1981 to defend the interests of recording device manufacturers, such as Fujitsu. (David Rubenstein, political insider and founder of the Carlyle Group, was hired by the manufacturers to organize the HRRC.) Japanese manufacturers - the dominant makers of VCRs-had found their business threatened by a lawsuit that was challenged all the way to the U.S. Supreme Court. In Sony Corporation of America et al. v. Universal City Studios, Inc., et al., (464 U.S. 417), often known as the "Betamax case," media companies sued manufacturers of VCRs for enabling what media companies claimed was copyright 
infringement by users recording off-air. The Supreme Court decided in favor of Sony both because the creation of the tool did not qualify as contributing to infringement and because private-use home taping was fair use. Media companies continued to be on high alert for infringement, and HRRC girded for future attacks.

The HRRC team drew talent from top lobbying and legal firms, with skills ranging from public campaigns to insider Hill politicking to treaty negotiations. It also had strong public support: American consumers loved their videocassette recorders (VCRs) and could be counted on to protest if someone tried to take away their ability to record and timeshift video (fast-forwarding and rewinding content). At the same time, however, the HRRC negotiated with media companies over an acceptable solution to copy protection, which would allow coalition members to continue selling devices.

The HRRC had, by 1995, an impressive history of successfully defending its interests. 49 After almost two decades, it was used to winning against IP interests, given strong public support for its products. But the DFC offered something of unique worth to the HRRC: librarians. "There's a librarian in every district," said one interviewee who requested anonymity. "Our interests were aligned enough... From their perspective, [the librarians] had a dream team of specialists [the librarians] could never have built or even imagined on their own. What we had were nice librarians to put forward."50

The DFC also had allies in computing companies, for which fair use was also extremely important. Fair use protected reverse engineering, as the 1992 Sega v. Accolade case (977 F.2d 1510) demonstrated, and reverse engineering facilitated interoperability-"the ability to make a new product or service work with an existing product or service." 51 In this lawsuit, a third party game designer, Accolade, in order to identify and replicate the code that facilitated a program's operation on the Sega Genesis console, temporarily copied three Sega properties in the act of decompiling them. Sega argued that both the acts of copying its creative code and re-publishing a functional portion of it constituted dual infringements of Sega's copyrights. The Ninth Circuit Court of Appeals disagreed. Content considered strictly functional, as opposed to expressive or creative, is not protected by copyright law. The court found that Accolade only republished what facilitated the interoperability of games on Sega's console. Furthermore, the act of copying the creative code to access the functional bits through the process of decompiling was protected by fair use. Sega had hoped to force independent game designs to license from them directly. Accolade's solution for creating titles for the Genesis console without Sega's technical authority did not infringe on Sega's IP, the court found, and was good for competition.52

Although IBM, the behemoth in the computing industry at the time, strongly opposed interoperability and thus, like Sega, sought to thwart reverse engineering through technical and legal measures, most companies agreed that interoperability was the engine driving both commerce and innovation. Furthermore, it benefited consumers who were provided with a greater range of products at cheaper prices. Jaszi and Samuelson similarly saw interoperability as critical to promoting the robust production of new culture online. Each had filed amicus briefs in the Sega case alongside the Computer and Communications Industry Association (CCIA) and the American Committee for Interoperable Systems (ACIS), which employed lawyer and technical expert, Jonathan 
Band. Band knew Jaszi and Samuelson as allies through his experience representing ACIS and was familiar with the team from HRRC as well. The ultimate partnership of the HRRC, CCIA and ACIS through the formation of DFC was a "win-win," Band reflected. "A convergence of interests-it was to everyone's benefit to be in the same coalition." 53

Such an alliance was new for the computing technology businesses. They had largely stayed out of the home-taping wars that had birthed the very focused HRRC. This was not their fight, so long as the arrangement brokered between the media and the home recording companies did not influence the design of computing technology industry's products.54 The Sega ruling, on the other hand, had enshrined the discrete copying of functional code as lawful for reverse engineering, seemingly cementing the core IP rights the computer industry required to compete in the new century.

Lehman's maximalist reimagining of IP for the Internet Age changed that. It would undermine the recent Sega victory as well as the Betamax precedent within the digital space while creating entirely new domains of IP related conflict. In the plan put forth in the Green Paper, temporary copies of content made in the random access memory (RAM) of a server, router, modem, or personal computer while loading information through the Internet would constitute a violation of copyright law, presenting a host of potential liability issues for device manufacturers, Internet service providers (ISPs), and consumers.

All three could be liable, differently, for copyright infringement charges. Direct liability is an immediate actor's liability-say, that of the individual infringer(s). Contributory liability occurs where a third party knowingly induces, causes, or contributes to someone else's direct infringement-say, the ISP that allowed the individual(s) to load an unlicensed copyrighted image. Vicarious liability can be assessed in cases independent of a third party's knowledge or awareness of direct infringement-say, a device manufacturer that knows an individual could potentially use its device to commit an infringing act.55 As the Green Paper imagined digital copyright policy, multiple parties could be found liable for infringements resulting from each unlicensed RAM copy generated when the image was viewed online. Even if users didn't have an internet connection, the framework proposed by the Green Paper would ultimately make the RAM used in loading third party software applications illegal acts of copying as well.

This proposal divided the computing world. The Green Paper's framework benefited the software protection interests of computing businesses represented by the Business Software Association (BSA). While only a few hardware manufacturers opposed a market based on interoperability by the mid-90's, many of these same computing companies were also creators of software content. For BSA founding members such as Microsoft, IBM, and Adobe, joining forces with legacy publishing interests and their consortia provided access to veteran rent-seeking expertise.56 The overlap of interests resulted in the Creative Incentive Coalition (CIC), which, in addition to the BSA, included, the Software Publishers Association, Viacom, the Association of American Publishers, The McGraw-Hill Companies, the Motion Picture Association of America, the Recording Industry Association of America, Time, and Warner, Inc.57 
CIC members, who Lehman had often worked with before, had direct access to the NII task force, and the Green Paper's proposal of a new database copyright benefited both software companies and print businesses transitioning to an online marketplace. Collections of data had long been considered exempt from copyright protection due to a lack of creative merit.58 The ability of core Internet computing technology to freely access databases so as to query them and perform basic networked operations such as "search" was fundamental to user engagement online. A database copyright would make these functions cost prohibitive, dramatically limiting the public utility of the Internet while presenting further contributory infringement issues for computing companies around the RAM copies of data collections.

The Green Paper's maximalism galvanized a previously unorganized coalition of countervailing interests. But those newcomers to the copyright issue were not necessarily fully informed. Copyright was either a new or peripheral issue for many in the computer industry at the moment of the Green Paper. Ed Black, director of the CCIA later recalled,

The content people were very well funded, they had been fighting the battles for years, they were diverse geographically, and they were not distracted by a lot of second, third, fourth tier issues. For all of my companies, and some others, there were a lot of other issues to fight. Getting copyright to be a constant high priority was virtually impossible. You had to settle for getting as much attention as you could, and remind people, "You have to care about this." Silicon Valley companies had a tradition for many years of avoiding Washington policy. They weren't staffed to provide the kind of support activity to play in the DC world on a wide range of issues.59

Black, a seasoned political operator, understood that balanced copyright was inextricably linked to his members' businesses. CCIA's slogan was "open markets, open systems, open networks." He also believed that there was a meaningful overlap between nonprofit interests and those of his industry on the issue:

I went back many years as a huge believer in the First Amendment. Our industry in particular was founded on those bedrock principles of a free and open society. The early part of the industry flourished because people just traded information[;] they were excited by ideas... We were dedicated to promoting the interests of our industry, which included the users of our products, which then extended to the public interest. I believed it was a wise policy not to look at narrow parochial short-term interest, but what is the impact on our users-that is, society at large.60

He had seen IBM try to leverage copyright against Microsoft: "The extreme use of IP as a weapon was well known to me." For all of these reasons, Black and Jonathan Band of ACIS committed their associations to the DFC effort.

The last group of DFC allies were telecommunications and proto-Internet companies such as Prodigy and America Online (AOL), which collectively lobbied as the Ad Hoc Copyright Group. In addition to holding these businesses contributorily liable for facilitating RAM copying, the NII taskforce's proposal sought to make transmission providers generally liable for the potentially infringing behaviors (pirating, decryption, 
etc.) of their users. The lack of a safe harbor provision - that is, a protection from shared liability with their users - threatened their businesses to the core. The Ad Hoc Copyright Group united with the DFC during the first attempt to pass legislation and was involved in the WIPO negotiations but eventually dropped out to fight on its own. In the second round of legislation, they shared information with the DFC, but after winning their argument on contributory or intermediary liability in April 1998, the Ad Hoc Copyright Group ended its collaboration with the coalition.61

At its peak, the DFC had 42 institutional members and represented perhaps 3 million direct members. It also claimed to represent consumers using some of the most popular technology of the day and the general public via various library associations (see Appendix 2). One advantage the DFC had in securing loyal allies, Black noted at a public event, was the totalizing nature of the IP interests' attempt to control Internet traffic: "The excessive greed on the other side put a light on us, and we could play a Paul Revere role. It wasn't obvious to telecom companies how much their industries would be affected. You have to thank your enemies for their overreach." 62

\section{Trust and Pragmatism}

The coalition worked generally in consensus, unlike the CIC. This was universally noted in our interviews, often with appreciation for its relative rarity. The group quickly established that no action would be taken and no statement issued on DFC letterhead without unanimous approval. Members refrained from leaking information, and when interests had to separately negotiate, they alerted each other beforehand.63

Partly this was pure political calculation, and partly it was mutual confidence in the expertise each group brought to the table. "We implicitly trusted folks in the coalition that were working on things that we didn't have experience with. They trusted us on library things," recalled ARL's Adler. She was fully aware of the kind of value librarians brought to the commercial players' game: "We would give cover for some of the industry folksand they knew that. Going into Hill offices with them gave them a good glow." 64 The anonymous political insider recalled, "Librarians were eh, so-so as a political force. They didn't have the muscle of industry, or the money. But they are good at what they do... Prue [Adler] was very smart politically and well connected and able to get the right person."65 Interviewees also pointed out the human element. "A big part of the trust was personalities. They were dealing with people [that] they could trust in us," the political insider said. In Band's mind, "What made it unique was the people involved actually liked each other." 66 Indeed, all of the DFC interviewees were still on friendly terms more than two decades later. Many of them appeared at American University's celebration of Prue Adler's career when she retired in 2019.67

Because of the depth of experience with Hill politics on all sides, and because of institutional goals and memory, all the participants agreed on a pragmatic approach. For instance, when Bruce Lehman took his task force's plan to WIPO, none of the DFC representatives endorsed a goal of trying to kill the treaty. In contrast, other nonprofit organizations held out hope for this very goal. Jamie Love, who had focused on drug patents previously and who had also attended WIPO but was not yet part of the DFC, strongly supported the strategy of killing the treaty rather than negotiating language.68 Rather, DFC members agreed on the strategy of altering language. All actors were 
aware of the moment, as Band said, as "just one battle in a long war. We're repeat players, we can't take advantage of a situation for temporary interests. We know we will need each other again." As well, none of the players needed credit for success. Indeed, it was deeply important to all to avoid being named or singled out. As the insider's desire for anonymity shows, for some it remains a central strategy.

From the start, the DFC knew it needed a good slogan. Robert Schwartz, legal counsel on the HRRC, said, "Hollywood could always say, 'We need to stop piracy in China.' Our side didn't have a sound bite." 69 With fair use uniting them, the DVD settled on a "sound bite" that focused on "balance" in copyright-balance between monopoly rights and what later was to be called user rights. This was a key word in describing their position, one the DFC used for both industry and noncommercial arguments.

This was a familiar position for librarians, and one that aligned as well with Jaszi's own intellectual formation. At the same time, it signaled respect for the interests of copyright holders. The DFC was not anti-IP, but pro-competition and pro-knowledge. DFC members wanted to ensure that digital copyright enforcement frameworks provided equal incentives for creating new culture online and rewarded valuable contributions. With the language of balance and competition, and high-profile support of major technology companies such as Fujitsu and Sun Microsystems, DFC quickly found an audience on Capitol Hill.

The call for balance influenced official action. For instance, in decisive interventions to stall out the first CIC-backed bill, H.R. 1861, Sens. Chuck Grassley (R-IA) and Paul Simon (D-IL) wrote a letter to the head of the Appropriations Committee in September 1995. Using the DFC's language, the letter protested that a provision in the bill would affect vital public interests as well as commercial interests, by losing balance; it "would dramatically change copyright law and could result in imposing direct, vicarious, and contributory copyright liability on educational institutions, libraries, Internet service providers, telecommunications companies, software developers, and hardware manufacturers." 70 The preamble to the 1996 WIPO Copyright Treaty also directly reflected the DFC's message of a need for balance: "The contracting parties... recognizing the need to maintain a balance between the rights of authors and the larger public interest, particularly education, research and access to information ... have agreed as follows."71

\section{Treaty Negotiations}

At the 1996 WIPO negotiations held on the eve of the winter holidays in Geneva-NII legislation having long since ground to a stalemate in congress-Seth Greenstein represented both the HRRC and the DFC. While not a part of the official delegation to Geneva, the DFC still managed to out-maneuver Lehman's envoy by building a voting coalition among smaller nations that embraced the framework of balance, effectively hamstringing the official U.S. agenda. In courting allies, Greenstein carefully linked the language of public interest and commercial interests. He shared his argument with members of the DFC: 
Both in the context of Section 1201 of the NII Copyright Amendments bill and this WIPO proposal, general language covering a wide range of acts and a broad scope of devices has time and again proved to be prejudicial to fundamental public interests such as fair use, and unfair to manufactures of devices having legitimate uses.72

In building support for his argument, Greenstein and others developed a solid front with other nongovernmental organizations, with developing countries, and with telecommunications representatives to push back against the U.S. position. "Balance" became a banner of the allies. The balancing concept also put them in a good position to negotiate since they were not positioning the DFC or its members as anti-copyright but pro-balance. Greenstein routinely checked in with the American delegation and strove for industry compromise, which was also the goal of U.S. negotiators. They told him privately that Lehman's abrasive approach led to disorganization.73 Greenstein also had negotiating meetings with the IP lobby, and telco lobbyists attended nightly phone calls to DFC members. The telcos worked with DFC to block attempts to declare all temporary copying in computer memory (RAM) as belonging to the copyright holdersomething that would have left all telecommunications operators vulnerable to infringement charges.

In his daily reports to the DFC members, Greenstein celebrated the way balance had become a rallying cry for, among others, South Africa, Korea, Singapore, Australia, Germany and Norway:

It was rare in the past that countries called for a balance of rights or fair use. Today, it was a main focus of discussion. A short time ago, the "primary purpose or effect" standard [for banning devices designed to break encryption] was broadly acceptable with little dissent except from three NGOs. Today, there was widespread recognition of the adverse impact on public and commercial interests. This all is largely made possible by the extraordinary efforts of all of our respective groups...I think we all can be justifiably and extraordinarily proud, but the opera ain't over 'til Bruce Lehman cries uncle. 74

When Lehman gave the last speech for the U.S. delegation, he ended it with, as thenrookie DFC representative Adam Eisgrau later recalled, "a great paean to fair use in the US and our economy. That's not what people would have anticipated Mr. Lehman saying, but those were the instructions he got." 75 The DFC's negotiation strategies had worked, and the White House had told Lehman to moderate his message. Balance ended up in the preamble to the treaty. The coalition's success took IP interests by surprise. Many years later, one of the IP lobby's strategists described, with some emotion, the DFC's opposition as having the Lehman proposal be "hijacked." The IP interests had not anticipated and had underestimated the DFC.76

WIPO negotiations resulted in general and vague treaty language, which was a remarkable overturning of Lehman's own expectations. He recalled that he had been confident, when entering the negotiations, that the U.S. maximalist position would dominate. It was why he had sought out Geneva in the first place. And no one on the DFC side had expected to stymie the U.S.-WIPO agenda; indeed, as Eisgrau recalled, 
"Playing to a draw was considered a significant win." 77 But they had won more than that. The vagueness of the treaty's language now allowed the U.S. to avoid implementing legislation. The treaty, as written, signified little more than a good faith agreement between nations. DFC member and Sun Microsystem's representative to the WIPO negotiations, Peter Choy, reported back to colleagues,

[C]ompared with the White Paper, and where we were four months to two years ago, these outcomes... represent a significant victory for DFC and ACIS [computing equipment manufacturers]. We didn't get everything we asked for, but achieved a great deal more than the USPTO [Patent and Trademark Office, which Bruce Lehman headed] would have been willing to concede; our lobbying in the administration and of the nations in the WIPO was clearly effective in raising our concerns to the level of domestic and worldwide visibility. 78

A draft DFC press release on Jan. 15, 1997, three weeks after the negotiations concluded, used the headline, "WIPO Treaties Embrace Balance." Absent from the copyright treaty, it noted, were copyrights in RAM reproductions, intermediary liability for OSP/ISPs, broad penalties on home copying/taping, and IP protection for databases ("the conference delegates decided that it required further study").79 Finally, the treaty preserved nations' rights to develop copyright exceptions.80

\section{Legislation}

The DFC members hoped that they would avoid domestic legislation via the vague language of the WIPO treaty. They were wrong. Lehman, as he later recalled, had entered WIPO negotiations with the express goal of justifying new legislation in the U.S. (a tactic known as "policy laundering"), and he intended to use the outcome as a means of forwarding that agenda.81 On his return, he won support for legislation from a Clinton Administration that was already deeply committed to a vision of an information superhighway fueled by commerce and that was increasingly eager to settle the terms under which the superhighway would operate. Despite advancing bills that reconstituted previously failed frameworks, in 1997, Lehman finally found momentum in Congress.

As this momentum mounted, the DFC developed its consumer/user-oriented public relations campaign. With funds from the List Foundation, a private family funder with a commitment to the public interest in communication, DFC members carried the message of "balance" they'd honed during the WIPO negotiations into various public campaigns.82 The DFC's 1997 public campaign combined national and local press with broad grassroots work. The HRRC drew on its connections with thousands of video retailers throughout the country. The HRRC developed promotional materials that deliberately had a DIY look. "We were trying to make sure it looked like we weren't heavily funded. So a lot of the stuff looked like it had been put together by a kindergarten teacher. But it worked," recalled Ruth Rodgers, who coordinated much of the public campaign: 83

We had standup signs, placards, we put them up in video stores, or the conventions, where you could tear off a postcard and send it back to us. We would note where it was from and send all those postcards to a member of Congress...And we got a lot of good 
press. We would do ads in Billboard magazine, and in Rolling Stone, saying the songwriters were behind us, and the RIAA was trying to kill these indie songwriters, anyone not under contract-that got a lot of publicity....We were emphasizing the harm to the American consumers, and that was getting out. We would write up pieces and send them out [to local newspapers in relevant districts] —op-eds or little blurbs that would go into weeklies or local newsletters or free papers. What was going on and how they could help, our phone number. We had an 800 number, and when they called, we signed them up to send a letter to their member of Congress. 84

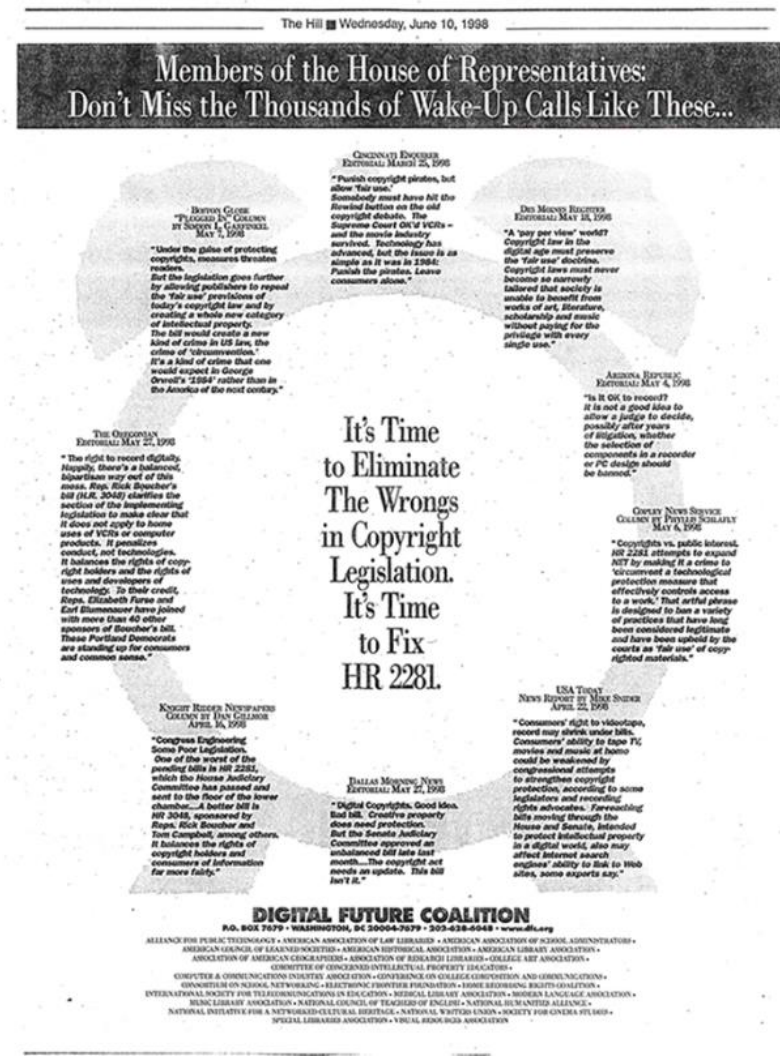

The DFC enacted their grassroots lobbying in part through a coordinated local and national
press campaign that relied heavily on editorials, depicted here in this June 1998
advertisement in The Hill. Record courtesy of the Program on Information Justice and
Intellectual Property, Washington College of Law, American University, Washington, DC.

The messages of the op-eds and ads linked consumer interests with the public interests of balancing copyright: "Under the guise of protecting copyrights, measures threaten readers by allowing publishers to repeal the fair use provisions of today's copyright law and by creating a whole new category of intellectual property." 85 They also appealed to library patrons by asking them to respect "the Constitutional underpinnings of American intellectual property law" and "the need for balance" in the administration of moral rights. "It is fair to say that most people don't know what fair use is, but they do know what they can do in a library," wrote Adler, advising on the public campaign.86 Print ads and seeded editorials also linked home taping and library access with the concept of balance. 


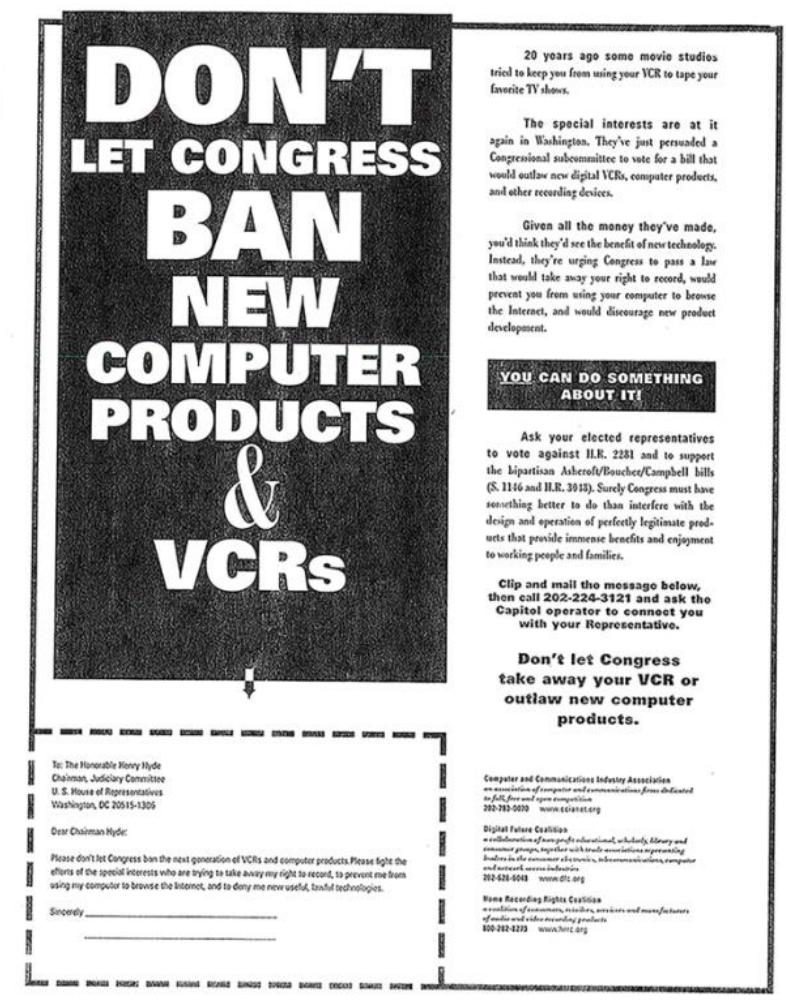

\begin{abstract}
The DFC drew support from the HRRC's strong grassroots base, first organized in the early 1980 's to fight legislation and lawsuits that threatened consumers' right to record on their new videotaping devices. The DFC connected long standing consumer interests to the digital copyright debates through the invocation of a familiar device (the VCR) and fight (the Supreme Court "Betamax" case). The HRRC playbook required little updating, as seen here in this advertisement, record courtesy of the Program on Information Justice and Intellectual Property, Washington College of Law, American University, Washington, DC.
\end{abstract}

Other ads sought to make copyright activism "As easy as ABC" (short for AshcroftBoucher-Campbell bills that supported DFC positions). Encouraging one's congressional representatives to support these bills, the ad stated, would ensure "an appropriate balance in the Copyright Act so that it protects intellectual property and affords public access to it." 87 Op-eds in papers around the country, including one in USA Today, encouraged Congress to support "balanced" frameworks, to reject "unbalanced" ones, to "balance the rights of copyright holders and consumers of information" and to "preserve the 'fair use' doctrine" to ensure balance." 88 This core messaging was carried onto its website, where users could read through issues, concepts and bill comparisons by clicking on clearly labelled tabs.89 DFC strategically sought to make its website a central hub for public education on the issues of fair use and balanced copyright.90

The CIC felt the sting of this approach. The group had also learned the dangers of underestimating the DFC. "The MPAA and RIAA started hitting back pretty hard," recalled Rodgers.91 The maximalist interests leaned heavily into the piracy trope. Jack Valenti warned, "Pirates have become more sophisticated. They are armed with new technology and hackers and others are going to invade the [internet]." CIC lobbyist Steve Metalitz drew a dire picture: "pirates can make limitless perfect copies, disseminate them around the world at the touch of a button, and carry out their activities with less fear of detection and capture than ever before." 92 
Along with the sting of the public campaign, IP interests perceived the DFC in general as deeply threatening, especially its nonprofit members. As executive director of the Association of American Publishers (AAP), former Congresswoman Patricia Schroeder wrote members as the final stage of legislation began:

There are serious questions about whether the bill, when it finally emerges from the Commerce Committee, will be anything that publishers, authors, musicians, software developers and creative artists can live with. The library community is intransigent in its opposition to any bill that effectively implements the treaties, and is unwilling to seek compromise. They are waging a campaign of disinformation about the true nature of the legislation, a campaign based of hypothetical scenarios that have no basis in market realities. They are holding Members of Congress hostage with predictions of the death of fair use-and indeed of our great national tradition of free public library service-if the WIPO implementing legislation moves forward.93

The CIC had more experience in copyright lobbying and more access to an IPmaximalist Administration than DFC's most seasoned members. The MPAA had been successfully generating IP policy domestically and abroad for decades. Furthermore, the $\mathrm{CIC}$ had star power. At one famous DMCA hearing, the RIAA brought Johnny Cash to congress to advocate for strong Internet copyright legislation. The DFC, on the other hand, had no celebrities and so had to counter with consumer and public-interest arguments.94 Once, the DFC got in a zinger. During the same hearing, the DFC, arguing that the proposed legislation was so flawed that it would lead to endless litigation, managed to make their position memorable. As Robert Schwartz recalled with stillevident pleasure, the DFC's representative said the proposed legislation might as well be called "A Bill Named Sue," a tongue-in-cheek reference to Cash's famous song. 95

In the face-off in public campaigns between celebrity power and consumer/publicinterest arguments, the exclusively industry membership of the CIC may have underestimated the consumer appeal of its opponents in the communications hardware and nonprofit sectors. Computer and VCR owners were highly invested in using their devices for consumer purposes as they liked. The CIC portrayed consumers as (often youthful) Internet users who were either pirates (as discussed earlier) or passive "surfers," just seeking to get entertainment for free. A commercial Internet, the CIC argued, could thus only be managed with stiff copyright protection:

As people surf through the information superhighway in search of interesting sites, one thing remains clear: content will drive the success of this revolutionary way to communicate. Ultimately, the value of the information superhighway-its ability to deliver social progress and economic growth-will depend directly on the ability to ensure strong copyright protection.96

DFC members often expressed the belief that the CIC piracy arguments were, basically, political theater. However, the CIC's continual focus on piracy, however politically convenient, may also have been a point of conviction. Lehman personally believed (and still believes) that the "information superhighway" was filled with "self-righteous young 
people who seemed to feel they had a right to steal anyone else's creation and do what they want to." 97

The $\mathrm{CIC}$ also portrayed the Internet as currently empty of creative work, with creators needing the protection of the IP interests. The organization's advertising campaigns moralized, framing DFC-backed legislation as "Teaching your kids to steal." They made legislation an "us versus them" proposition, printing magazine ads that said "They are wrong" in half-page bold letters.98 This message has continued ever since; generations of schoolchildren have received free materials from associations representing IP interests linking any kind of copying with stealing.99

\section{Teaching your kids to steal?}
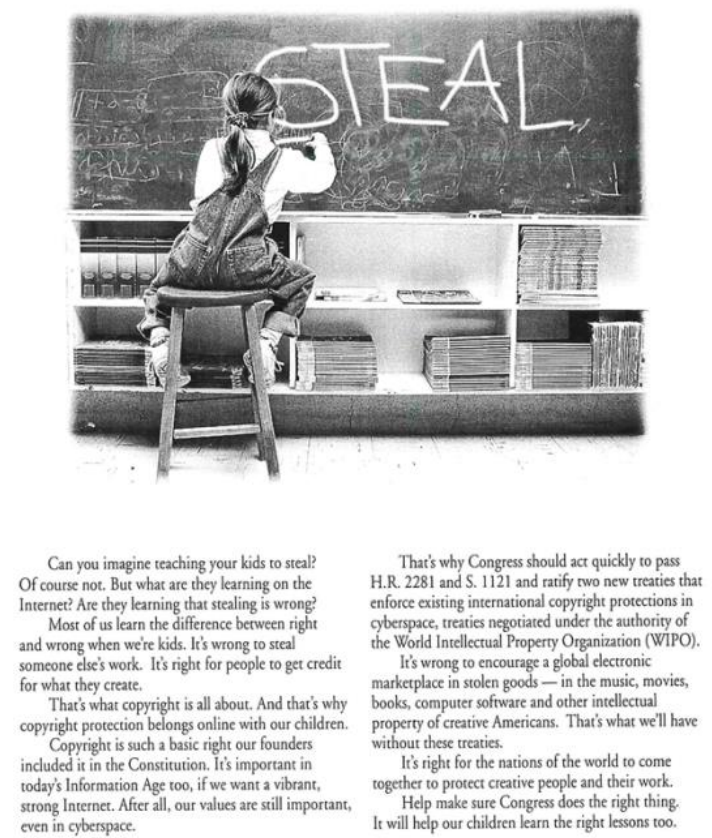

Copyright. It's the right thing.

Ratifv an American tradition.

The CIC vied for public support through blunt appeals to morality and even patriotism, framing copyright as "American." Record courtesy of the Program on Information Justice and Intellectual Property, Washington College of Law, American University, Washington, DC.

Group dynamics also distinguished the DFC from the CIC. One lawyer representing stakeholders in the CIC discussed (on the condition of anonymity) the "contentious" nature of decision making within the CIC. Parties drew hard lines even among each other and were resistant to compromise; some members were as much competitors as allies, and others had orthogonal interests to each other:

The Business Software Alliance was aligned in some respects with the Motion Picture Association but since their content was different, they were sometimes prepared to draw a line in a different place...even those who were trying to protect content had different views of how their particular content should be protected. Those had to be hammered 
out as well. We had meetings where "our" side would meet to agree on our lines, and then meet with ISPs who had a different view. 100

The CIC lobbyists were seasoned, had access to celebrities, and worked with legislators who were acutely aware of the value of media for their own political campaigns. The DFC had no celebrities and faced a number of legislators with little technological savvy. But the coalition had a professional understanding of the workings of the Hill, especially among the HRRC representatives, and the DFC was able routinely to mobilize its constituencies for Congressional visits. Thus, it made a claim, with physical bodies, to broad consumer interest. "We showed up on the Hill, all the time, all the time," recalled Miriam Nisbet, who had been legislative counsel for the American Library Association. "We had a committed group of people. You didn't have to worry if someone was going to represent their stakeholders. We were there, we were committed, we had practical examples, we had the public interest argument, but more importantly, we showed up."101 When they did show up-a group of seven or eight people representing different but united constituencies-they often faced legislators who had no idea about the technologies or about copyright implications. Their unity was one guarantor of their ability to educate, Ed Black later recalled.102

Robert Schwartz, legal counsel on the HRRC, recalled that the DFC and its allies had had the upper hand in political jockeying around the Green and White papers, because of the combination of a deep consumer base and the ubiquity of libraries in everyone's district. As well, the DFC demonstrated clout in Geneva: "Right through to 1994-6, the HRRC plus the emerging tech plus the library and user groups and consumer groups controlled the discourse and public perception." 103 That control would extend through early spring of 1998 with the DFC's communication campaign taking hold of the public's attention and new bipartisan co-sponsors backing their bills.104 The CIC was feeling the pressure. As Schroeder put it in a memo to AAP members:

After two years of effort, seemingly endless negotiations, victories and setbacks, and a heartening win in the U.S. Senate, the WIPO legislative process is on life support. We may lose the most important piece of legislation to come before Congress this year and in the process scuttle two vital international treaties essential to American interests. 105

\section{Compromise: Copyright Carveouts and Exceptions}

Opposition, however, stiffened the Clinton Administration's resolve, and the Administration increased its political pressure.106 As it brought more political muscle to bear, DFC allies began peel off.

This moment of carveout-when individual organizations no longer negotiated as a whole coalition and bargained for their own interests-was one that the members of the DFC had anticipated. "We understood the realities of business; you go as far as you can together," recalled Eisgrau. "We would have been upset if someone not only got off the train but pushed in the other direction. I never felt betrayed by someone cutting a deal."107 
The carveouts affected the core functions of the DFC. In 1998, the year the DMCA passed, only 10 members chipped in financially. The coalition's industry interests increasingly reallocated their contributions to the DFC back towards their own niche legal efforts. Groups like the HRRC and CCIA, which made enormous in-kind contributions of staff time and legal expertise, had always been low-level financial donors. Industry members wanted to avoid charges that the DFC was a front for corporate interests. 108 Now their contributions were even smaller, similar in size to those of the nonprofits. The second highest donation in 1998 was from the Modern Language Association at $\$ 10,000.109$ With the DFC relying entirely on contributions of this size, increasingly deprived of in-kind legal support and general labor, the group's ability to negotiate in the closing stages of policy formation diminished.

For the first time, closed-door meetings between the DFC's industry affiliates and the publishing consortia in the last round of legislating did not include nonprofits. Individual interests struck deals for themselves. Most powerfully, telecommunications and protoInternet providers won exemptions from intermediary liability in the DMCA, which amended the Copyright Act to include a new section, Sec. 512. They horse-traded it for a provision that criminalized circumvention of encryption (a technical protection measure, or TPM), incorporated into the Copyright Act as Sec. 1201. The loss of the telcos led to other commercial interests peeling off. Schwartz recalled, "1201 wouldn't have passed if it wasn't for [telcos] getting 512. Losing the telcos was a big blow." Seth Greenstein affirmed, "The online world then was AT\&T, MCl, the big telcos, and they could stop the bill in its tracks, for certain. They had been active at WIPO. Once 512 came in, they disappeared." 110 The relationships between DFC members continued, but the terms changed. "We kept up the grassroots work," recalled Schwartz, "but it shifted. It now had to accommodate the deals we were making into the story we were telling the public...The message became compromise. Even the DFC message was nuanced and compromised."

Some coalition members were losing their clients' patience. For the HHRC's clients, the consumer electronics manufacturers who had been fighting with IP owners for two decades about home taping, "there was lawsuit fatigue." Even an imperfect deal was beginning to look better than unpredictability.111 Membership contributions dried up; periodic matching donations of $\$ 25,000$ by the foundation of Mitch Kapor (Lotus 123 developer and Electronic Frontier Foundation co-founder) could no longer be matched.112

This turn to pragmatic individual interests' search for the best deal for themselves did not surprise the library interests, but it did shock other public-interest advocates.

Schwartz added, "People like Pam Samuelson and Jessica Litman were appalled by the deals the Consumer Electronics [Manufacturing] Association [known today as the Consumer Technology Association] made."113 Jamie Love similarly found his deepest suspicions confirmed.114

Jonathan Band, who was representing companies concerned with interoperability, said,

In 1997, it was clear we couldn't kill the DMCA once joined with safe harbors [Sec. 512]. The telcos didn't care about our issues-they were focused on safe 
harbors. AOL was the exception, but most proto-Internet people didn't care. We were all going to have to try to get our own exception. And we all understood that we would each drop off once we got our carveout. We all believed this was bad policy. But at the same time, if you're a lawyer repping a client, you go for your client's interests.115

$\mathrm{CIC}$ representatives looked upon the telcos' safe harbor arrangement as a major loss. They found themselves dismayed at the idea that telcos were being let off the hook for what they feared would be massive systematic infringement. It was "a major thorn in the rights holders' side," said Lehman.116

The nonprofits were left negotiating for carveouts without their powerful partners. Libraries stood to lose almost everything, with a few arcane exceptions. For instance, they won the right to break encryption when deciding whether or not to purchase an item. Adam Eisgrau, a supporter of Arnold Lutzker who represented the DFC and libraries, was at the bargaining table until 3:30 am on the final day of negotiations over what would become the DMCA bill, hoping to insert the phrase "fair use," or at least a clause useful to the nonprofit members of the coalition generally. Lutzker finally in desperation created, on the spot, the proposal for a clause requiring the Copyright Tribunal to hold triennial decryption penalty waiver hearings for people whose work was impaired by the requirement.117 This became Sections 1201(a)(1)(B)-(D) of the DMCA. "After the DMCA passed, it took quite a while for me to reconcile, to not consider that a defeat, a big one," recalled Eisgrau. "Friends within and outside the coalition had more perspective. Their attitude was, the bottom line is, fair use is alive and well. The rulemaking will do something." 118

At the same time that its coalition was dissolving on the DMCA front, the DFC won a major victory on another front. In a parallel fight, the coalition blocked the copyrighting of databases in the U.S. once more-and at a decisive moment. In the spring of 1998, the House passed a database protection bill. By late July it was merged with the DMCA.119 Prue Adler and Peter Jaszi alerted the coalition about the merger. A vote for the legislation that included the painstakingly negotiated Sec. 1201 carveouts protecting the DFC's manufacturing members' interests was now also a vote for database copyright. Convinced their work negotiating was over, Jonathan Band managed to rouse the litigation-fatigued tech manufacturers one last time to standby the DFC's efforts and work to excise the database portion of the bill.

One of the coalition's levers was to split IP holders. Jamie Love realized that newspapers and magazines would have to license statistics from major league sports, and that brought those media interests to the DFC's side of the argument. Financial organizations including Bloomberg realized that not only would costs for data skyrocket, but some data would become entirely unavailable, lowering the quality of financial information.

Another approach was to gather new allies. On the commercial side, Yahoo as a latebreaking member of the coalition added important heft, and the Chamber of Commerce eventually came in on the DFC's side. Finally, the DFC won concessions at the White House. 
In August 1998, the General Counsel for the Department of Commerce wrote Senator Patrick Leahy, the Ranking Minority Member of the Senate Committee on the Judiciary, with the "consensus position" of the Clinton administration: any database amendment entered into the DMCA should have a guaranteed "de minimis effect" on noncommercial research.120 The White House's language on database IP was now on par with National Research Council's. In the opinion of scholar Mark Davison, the National Research Council's influence consulting on the matter was shaped by Samuelson and Reichman's expertise.121 With pressure mounting on multiple fronts, the Senate eventually stripped the amendment altogether.122 This was a win that changed the landscape for Internet-enabled communications technology and could not have happened without the formation of the DFC around the DMCA.

The DFC continued for a few years after passage of the DMCA and the defeat of copyright protection for databases. By 2002, the coalition disbanded as members pursued other agendas, and its minimalist funding could not be sustained. Members would reunite informally to defeat one last piece of database legislation (the second attempt to pass such a law post-DMCA), the Database Misappropriation Act of 2003.

\section{Legacy}

As with the WIPO legislation, the DMCA that finally passed looked dramatically different from the roadmap provided by the Green and White Papers. Users maintained their freedom to use media devices as they saw fit (albeit with TPMs); ISPs avoided liability for third-party infringement; affected users were granted exemptions from anticircumvention provisions.

Users maintained their freedom to use media devices as they saw fit (albeit with TPMs); ISPs avoided liability for third-party infringement; affected users were granted exemptions from anti-circumvention provisions. This was not just a set of concessions. It was a refusal of Lehman's vision of a totalized copyrighted environment in which all non-authorized uses were prohibited or taxed.

For DFC members, this was a harshly limited version of victory. The concessions they won did not really reflect balance in copyright, and fair use was never even invoked. Bruce Lehman, by contrast, today believes that the compromises in the DMCA jeopardized the future. The forces he imagined in 1994-forces he believed wanted everything on the Internet for free-succeeded in creating a leaky copyright system online, with dire consequences: "I hope the Naderites [followers of consumer activist Ralph Nader] are happy. We wonder why $1 \%$ runs everything. Because individual creators are absolutely, totally disempowered. They have zero rights; everything they do can be stolen." 123

Blocking database protection was perhaps the DFC's biggest achievement. And its members still regard it as such. Miriam Nisbet, ex-legislative counsel for the American Library Association, said, "This 'non-event' was a very important event." But because it was an act of blockage, it was less well recorded in histories of the DMCA and its related issues. The United States is one of a small group of countries that does not 
have a codified database right. The European Community enacted its own database Directive in 1996, independent of the WIPO.124 The EU conducted an evaluation ten years later and found no discernable impact on the production of databases. A new right was passed in response and a subsequent evaluation by the EU once more found no impact.125 Mark Davison provides this historical assessment:

The U.S. and the EC [which later dissolved into the EU] have provided a world laboratory for the value and effectiveness of database protection. The U.S. legal position has operated as the control test and the [EC's] Directive has constituted the innovative experiment. The U.S. has not suffered as a consequence of the lack of a database right and the EU has not made any demonstrable gain from having it... The lack of database protection and, in particular, its defeat in the Senate in 1998 was the direct product of the input of pre-existing, institutionalized, funded, and Congressionally recognized scientific and educational lobby groups such as the National Research Council. Without them, the U.S. would have passed legislation that was very similar to the Directive.126

The DFC was not, however, able to keep digital protection measures off digital content. The DMCA resulted in what many information activists and critical policy scholars see as a sea change in copyright policy and a set of obstacles to innovation and expression. Gillespie argues that the DMCA is "the most dramatic change in the history of U.S. copyright law" because it links copyright policy to specific technology for the first time.127 For some, the DMCA is worse than the original White Paper-model bill that the DFC helped to defeat. Litman argues that the DMCA as it emerged from years of wrangling was even more "pernicious" than the original, for being so long, confusing, and having a "laundry list" of narrow exceptions that do not appropriately balance the "sweeping new rights" given to rightsholders. 128 Her criticisms of the DMCA's weaknesses largely echo the sentiments held by some of the most longstanding DFC activists we interviewed. The rightsholder lobbyists we spoke to, by contrast, were divided on whether the exceptions were functional or not narrow enough. Otherwise, they shared the view that the bill represented a working arrangement.

So then, was it worth the fight? It is impossible a world in which the DMCA was never passed or passed with major concessions to the DFC's public interest concerns.

Technology companies have certainly been able to develop products and services-for instance, all search functions-under the DMCA that may well have been impossible to execute with a policy that copyright-protected databases, or that made platforms share liability with their users. Social media companies have enabled content to be rapidly shared, hyperlinked, remixed and indexed. Ordinary users are now familiar with the fair use doctrine, the conscious use of which has been vastly expanded. In short, under the original bill, life would probably have been different, for better and worse.

But in reality, the DFC and CIC battled over balance in copyright because there was no way either side could avoid such a fight. Interviewees on both sides repeatedly described alarm over how high the stakes were. The current law has indeed created obstacles to freedom of expression and exercise of fair use. The 1201 rulemaking exception has harsh limits, requiring users to organize and return every three years to defend what they have previously won. It does not explicitly recognize fair use as a 
reason to break encryption, and the exemptions are hard to use, even when users win them. As a recent study showed, many users are unaware that they might qualify for an exemption and how specific exemptions apply to their work. (The study also found that once users were notified, they could appropriately apply the exemption to their work.) 129 Similarly, Sec. 512, which exempts ISPs from infringement charges if they take down work at a rightsholder's request, has created freedom of expression problems. For example, the Lumen database has ceaselessly recorded evidence that automated takedowns of legitimately fairly used material continue, and some copyright holders use takedown requests for censorship purposes.130

On the other hand, if we look at the 1201 exemptions granted since the passage of the DMCA, we can see that more has changed than any of the combatants in the process expected. The seemingly smallest change to Lehman's original vision, this little exemption clause - considered a mere throwaway gesture at the time-has gradually changed the DMCA itself more than any other provision. Exemptions have been won by filmmakers; noncommercial creators such as vidders, remixers and makers of audiovisual political criticism; cybersecurity analysts; independent auto repair companies; software preservationists; and teachers.131 The kinds of exemptions granted have become more expansive and, once won, are typically renewed. Indeed, the renewals have become so routine that in 2016, the Copyright Office held hearings to determine whether some should be made perpetual. 132

The nearly-nixed exemption mechanism brokered by the DFC in the final moments of negotiations has resulted in durable changes to the meaning of the law. Passage of the 2014 Unlocking Consumer Choice and Wireless Competition Act, the first legislative change to the DMCA since its passing in 1998, resulted from a rigorous triennial exemptions debate.133 A lead IP lobbyist deeply involved in the '90s legislative battle, Steve Metalitz, said that the exemption process was "the real afterlife of the DMCA." 134 A numerical count of participation in and results of the exemptions process demonstrates sustained and consequential activity. 135 Public participants ranging from individuals without legal representation to grassroots organizations and coalitions earn new and expanded carveouts each hearing. 136

1201 Hearings to Date: Exemptions and Participation 137

\begin{tabular}{|l|l|l|l|l|l|l|l|}
\hline & $2000^{138}$ & $2003^{139}$ & $2006^{140}$ & $2010^{141}$ & $2012^{142}$ & $2015^{143}$ & $2018^{144}$ \\
\hline Comments $^{145}$ & 235 & 50 & 74 & 19 & 674 & $40,000+^{146}$ & 181 \\
\hline Replies $^{147}$ & 129 & 338 & 35 & 56 & 18 & 50 & 77 \\
\hline Rules $^{148}$ & 2 & 2 & 3 & 2 & 1 & 6 & 1 \\
\hline Expansions $^{149}$ & $\mathrm{n} / \mathrm{a}$ & 2 & 0 & 1 & 3 & 2 & 5 \\
\hline Renewals & $\mathrm{n} / \mathrm{n} / \mathrm{a}$ & 0 & 3 & 3 & 1 & 1 & 4 \\
\hline
\end{tabular}


While successful exemptions do not mitigate the real censorship and innovation-stifling effects of the DMCA, they do provide a safety valve that would not exist without the DFC. These exemptions also continue to demonstrate the problems of the law more generally. As exemptions mount, so does evidence of the constraints on anticircumvention. (Furthermore, because no exemption is ever permanently installed in the law, the financial burden on nonprofits to organize and file their requests for exemptions and renewals every three years cannot be overlooked.)

The DFC's work has also had institutional effects. For instance, alerting international diplomats at the WIPO of the value of copyright exceptions and limitations began a new conversation. For representatives of many nations, this was the first time they encountered U.S. views that diverged from the official delegation's position, and it opened the door to new discussions and alliances.151 The Electronic Frontier Foundation (EFF), long resistant both to Washington politics and to IP issues, began to include copyright on its list of concerns. 152 Jonathan Band also built on the relationships he forged with Adler and the Association of Research Libraries. He opened his own firm, with a strong focus on public interest in IP, and is counsel to the Library Copyright Alliance. He has participated in many DMCA waiver processes, among others. And Gigi Sohn, who had worked with the DFC as a Ford Foundation program officer but who had ultimately decided not to contribute funds to the coalition (to the disappointment of DFC members), launched the nonprofit Public Knowledge (PK) with David Bollier using a Ford Foundation grant she received after leaving the Foundation.153 PK took many of the DFC concerns as its own when it launched in 2001 but without the same incentives for discretion and collegiality. 154 Thus, PK has been a challenging collaborator for DFC members, but it continues to be active on a range of copyright issues in communication. PK, EFF, and DFC joined forces, for example, when the Stop Online Privacy Act/Protect IP Act (SOPA/PIPA) legislation was proposed and backed by rightsholder interests. This Act threatened to break the basic lookup functions of the Internet in order to patrol piracy, but by working together, the alliance helped defeat it. 155 The content industry had once again painted infringement as an existential threat to the economy despite a thriving online content sector, said Band, who worked on the issue. $156 \mathrm{He}$ attributed the coordination of nonprofit and for-profit actors with an engaged public increasingly wellversed in information policy issues as elemental to defeating the legislation.157

The DFC created a policy network that still operates today. For instance, when the RIAA sued telecommunications providers in the early 2000 s over users' downloading practices, Verizon, among others, appealed to the DFC and won support for-and ultimately successfully defended-its position that the DMCA exempted telecommunications providers from such infringements claims.158 "You formed ties and relationships," recalled Ed Black. "Gigi Sohn and others stayed in the game. The longer it lasted, the more the relationships could deepen among the members. It allowed communication among a variety of players who might have interacted less consistently otherwise."159 Jonathan Band commented, "Even though the DFC doesn't exist per se, its spirit continues, and we all still work together." 160 Prue Adler noted that DFC members still annually get together in Washington, D.C. during Restaurant Week.161

The DFC also has successor organizations. The Library Copyright Alliance, which Band now represents, grew out of the DFC and continues to be an essential policy coalition 
for library interests. The Recreate Coalition, mostly composed of a younger generation of activists, deals with many of the same issues as the DFC, although, as Adam Eisgrau noted, the Recreate Coalition may be unaware of its heritage. "It's fun to hear the 20somethings come up with new ideas that are actually old," he said.

And as a result of the DFC's wins in the DMCA negotiations, a now-lively new movement has formed: the "Right to Repair." 162 This movement advocates for interoperability broadly but especially in consumer and personal devices. It seeks DMCA exemptions from anti-circumvention from the Copyright Tribunal, for the breaking of encryption in order to conduct repairs. While TPMs are not necessarily difficult to crack, the act of doing so (barring a codified exception) still constitutes a crime under Sec. 1201. Selling tools that break TPMs is also illegal under Sec. 1201, a provision Right to Repair has also sought to remove from the law. Like the DFC, which emphasized a balance between public and private interests in copyright protections, Right to Repair steeps its consumer rights agenda in a commercial argument. Tinkering, modification, and personal repair, the movement argues, facilitates a robust secondary market for tools, aftermarket parts, repair services, and fixit guides. Among the Right to Repair's earliest victories was gaining a DMCA exemption, using Sec. 1201, for breaking mobile device encryption (often known as jailbreaking), the only subsequent legislation that has altered the DMCA. The organization iFixit, which contributed to the jailbreaking exception, shares grassroots knowledge on repairing devices from phones to cameras to cars to hot tubs to old typewriters.163 The Repair Association (RA), the movement's main trade consortia, counts 30 nonprofits. Like the DFC, the coalition includes a strong library and public interest organization constituency. It also includes 20 corporate members. (Co-founder Kyle Wiens of iFixit is on The Repair Association's board of directors and is its head strategist.)

The RA's public-private composition distinctly resembles the DFC's. This may be due in part to the group's origins. The RA's early members met through the 1201 hearings. 164 The DFC's influence on those hearings is indelible. The EFF, who as members of the DFC developed their positions on digital copyright, provide strategic legal support to the RA (and others) in relation to the triennial hearings.165 The RA also collaborates with PK in a similar capacity -another organization drawn into IP policy issues through the DFC.

Like others who participate in the exemption process, iFixit's Wiens is under no illusion about the limits of DMCA exemptions. They take enormous resources of time and legal knowledge, and they result in narrow exemptions. Nevertheless, he sees the hearings as an opportunity to gain a public interest foothold and push for legislation at a state and national level. The RA has used the Sec. 1201 exemption process to address issues from election security to environmental health (implicated in 1201 rules affecting the recycling of technology). The RA is using the DMCA exemption process systematically; it has targeted ten areas in which it will file exemptions under Sec. 1201 before the Copyright Tribunal. 166 One of the right-to-repair movement's high-profile issues, farm equipment repair, became an issue in the 2020 Democratic primaries. 167 Reflecting on his coalition's successes, Wiens commented, "We stand on the shoulders of giants," although he was not aware of the DFC itself. 168 While not genetically DFC, the RA clearly emerges from the coalition's historically overlooked copyright activism. 
As evidenced in the Right to Repair's tactics, DFC's activism also created a trope that became part of U.S. policymaking and public discourse: the need for balance. Previously, commercial interests had depended on consumers' anti-taping fears and telecoms' deep lobbying connections. The argument for balance refocused the discussion on the Constitutional purpose of copyright policy: to incentivize more cultural creation. HRRC executive Ruth Rodgers noted, "People understood what fair use was more [as a result of the DFC]. There were concessions made to fair use. That's the long-term thing." 169 Since then, many professional communities have articulated their own standards to apply fair use in a digital era, finding it a crucial tool for creating new culture. 170

The trope is not without its critics. Some copyright activists today critique the notion of balance as reifying the ultimately colonial merger of property and creativity, which, no matter the terms, they argue, inherently promotes a system of stratified, individual ownership over collective prosperity.171 For those in the Global South who were not signatories nor invited participants in the Berne Convention and who have seen their creative resources commodified globally without local renumeration, balance can smack of neoliberal solutionism.172 Within a U.S. context, however, the concept of balance, anchored to the U.S. Constitution, has provided consistent pushback to copyright maximalism. In the 1990s and early 2000s, an alternative trope was developed by DFC member and IP academic Jamie Boyle and David Bollier, who developed the notion of the "information commons," invoking the specter of information enclosure.173 This formulation, however, never caught fire at the level of national policy.

\section{Conclusion}

Combatants on both sides have declared a flawed victory over the DMCA. On a panel about the DFC at the Washington College of Law, Band said, "I think sometimes people don't see what didn't happen. The motto for the DFC could be, 'It could have been worse." 174 Pamela Samuelson took the longer view: "If you look at the world Bruce Lehman wanted in 1995, and the one we have today, ours looks a lot more like the one I was arguing for." 175 IP advocates noted that the DMCA has been, with the exception of the 1201 exemption process, stable and has accomplished core goals of the IP side. "'Happy' and 'won' are not applicable to the legislative process," said Joel Jankowsky. "A legislative process is successful when both sides are unhappy. DMCA is a pretty good example of that. It is a crude instrument that was hammered out to get where we are today." 176

The history of the DFC demonstrates the greater role public-interest actors played in establishing the basic terms of IP on the Internet than previously acknowledged. The coalition's history demonstrates that minor wins, like the libraries' exemption mechanism, can become more important than anticipated. It shows that major wins that stop bad policy, such as the killing of database copyright legislation, need to be remembered as much as wins that create functional policy. Consumer and public interests can collaborate productively and in good faith with commercial actors if given clearly defined goals. Public-interest and nonprofit actors can bring to the negotiating process ideological strength and rhetorical advantage, all of which can expand public awareness and responsiveness of legislators in an enduring way. 
Just as importantly, the history of the DFC reveals the hidden long tail of public-interest activism. The DFC put in motion alliances and relationships that have lasted decades and been activated in other fights. It created the capacity for rapid responses to crises. It paved the way for new organizations. Its actions changed law and opened possibilities for new public interest activity.

All those relationships and institutions will be tested again. The DMCA was just one major stop on the road to digital copyright policy. The EU's Copyright Directive, discussions about Sec. 230 of the Communications Decency Act/Title V of the Telecommunications Act of 1996 (47 U.S.C. Sec. 230), and the Copyright Office's 2020 report on Sec. 512-which generally supported the rightsholders' argument that Sec. 512 was not adequately protecting them from Internet piracy-all mobilize copyright advocates, whose numbers and connections continue to grow.177 As Ed Black commented, "It's not a closed chapter. The arguments continue. The ideas that sparked the problems are alive and well and living in different sets of clothing." 178

\section{Notes}

We thank the staff of the Program on Information Justice and Intellectual Property at American University's Washington College of Law, especially Meredith Jacob and Michael Palmedo, for patiently facilitating access to the DFC archive over months. We thank our interviewees for their time and review. We thank Mariana Sanchez Santos, a $\mathrm{PhD}$ student at American University, for assistance in research.

1 The Digital Millennium Copyright Act, Pub. L. No. 105-304 (1998).

2 Robert Schwartz and Seth Greenstein, interview with authors, August 28, 2018.

3 Information Infrastructure Task Force, Intellectual Property and the National Information Infrastructure: A Preliminary Draft of the Report of the Working Group on Intellectual Property Rights (1994).

4 Bruce Lehman, interview with authors, March 15, 2019.

5 U.S. Government Working Group on Intellectual Property, Green Paper on Intellectual Property and the National Information Infrastructure 130 (1994); National Research Council, Bits of Power: Issues in Global Access to Scientific Data (Washington, D.C.: National Academies Press, 1997), 157-159.

6 National Research Council, Bits of Power, 160.

7 Jessica Litman, Digital Copyright: Protecting Intellectual Property on the Internet (New York: Prometheus Books, 2001), 135-140. 
8 Litman, Digital Copyright, 143-145.

9 Linda Birt, Suzanne Scott, Debbie Cavers, Christine Campbell, and Fiona Walter, "Member Checking: A Tool to Enhance Trustworthiness or Merely a Nod to Validation?" Qualitative Health Research 26, no. 13 (2016): 1802-11.

10 James Boyle, Shamans, Software, and Spleens: Law and the Construction of the Information Society (Cambridge, MA: Harvard University Press, 1996); Tarleton Gillespie, Wired Shut: Copyright and the Shape of Digital Culture (Cambridge, MA: MIT Press, 2007); Jessica Litman, Digital Copyright.

11 Litman, Digital Copyright, 194.

12 James Boyle, The Public Domain: Enclosing the Commons of the Mind (New Haven, CT: Yale University Press, 2008), 59.

13 Bill D. Herman, The Fight over Digital Rights: The Politics of Copyright and Technology (Cambridge: Cambridge University Press, 2013), 64.

14 Gillespie, Wired Shut, 176.

15 Hector Postigo, The Digital Rights Movement: The Role of Technology in Subverting Digital Copyright (Cambridge, MA: MIT Press, 2012), 45-51, 188.

16 Julie Cohen, Configuring the Networked Self: Law, Code, and the Play of Everyday Practice (New Haven, CT: Yale University Press, 2012); Lawrence Lessig, Code: Version 2.0, 2nd ed. (New York: Basic Books, 2006); Boyle, Shamans; Gillespie, Wired Shut.

17 Milton Mueller, Christiane Pagé, and Brenden Kuerbis, "Civil Society and the Shaping of Communication-Information Policy: Four Decades of Advocacy," The Information Society 20, no. 3 (2004): 169-185.

18 Philip Napoli, "Public Interest Media Advocacy and Activism as a Social Movement," Annals of the International Communication Association 33, no. 1 (2009): 385-429.

19 Joe Karaganis, "Cultures of Collaboration in Media Research," in Communications Research in Action: Scholar-Activist Collaborations for a Democratic Public Sphere, eds. Philip Napoli and Minna Aslama, (New York: Fordham University Press, 2011), 287-312.

20 Frank R. Baumgartner, Jeffrey M. Berry, Marie Hojnacki, David C. Kimball, and Beth L. Leech, Lobbying and Policy Change: Who Wins, Who Loses, and Why (Chicago: University of Chicago Press, 2009).

21 Litman, Digital Copyright, 145.

22 Jamie Love, interview with authors, October 5, 2018. 
23 Angela J. Aguayo, Documentary Resistance: Social Change and Participatory Media (New York: Oxford University Press, 2019); John Downing, ed. Encyclopedia of Social Movement Media (Thousand Oaks, CA: Sage, 2011); Sue Currey Jansen, Jefferson Pooley, and Lora Taub-Pervizpour, eds., Media and Social Justice (New York: Palgrave MacMillan, 2011);

24 See for instance, Part VI, "Law, Regulation and Ethics," in Routledge Reader on Electronic Media History, eds. Donald G. Godfrey and Susan L. Brinson (New York: Routledge, 2015), 492-581.

25 Along with work specifically on the DMCA referenced in this article, we note, inter alia, such examples as Allison Perlman, Public Interests: Media Advocacy and Struggles over U.S. Television (New Brunswick, NJ: Rutgers University Press, 2016); Robert B. Horwitz, "Broadcast Reform Revisited: Reverend Everett C. Parker and the 'Standing' Case," Communication Review 2, no. 3 (1997): 311; Whitfield Diffie and Susan Landau, Privacy on the Line: The Politics of Wiretapping and Encryption (Cambridge, MA: MIT Press, 1998), particularly its discussion of the Clipper Chip; Patricia Aufderheide, The Daily Planet (Minneapolis, MN: University of Minnesota Press, 1999), particularly its look at public broadcasting, access cable, DBS set-asides, and regulation of children's television; Victor Pickard, America's Battle for Media Democracy: The Triumph of Corporate Libertarianism and the Future of Media Reform (New York: Cambridge University Press, 2015), particularly its examination of the Fairness Doctrine and FCC public interest standards; Robert McChesney, Telecommunications, Mass Media, \& Democracy: The Battle for the Control of U.S. Broadcasting, 1928-1935 (New York: Oxford University Press, 1993).

26 Napoli, Public Interest Media Advocacy, 388.

27 James Madison, Federalist No. 43 "The Same Subject Continued (The Powers Conferred by the Constitution Further Considered)," The Independent Journal, January 23, 1788; U.S. Constitution, art. 1, §8, cl. 8; Lewis Hyde, Common as Air: Revolution, Art, and Ownership (New York: Farrar, Straus and Giroux, 2010).

28 Gregory Miller, "Reliability and Alliance Behavior," in The Shadow of the Past Reputation and Military Alliances Before the First World War (New York: Cornell University Press, 2011), 45-55.

29 Michael Levine and Jennifer Forrence, "Regulatory Capture, Public Interest, and the Public Agenda: Toward a Synthesis," Journal of Law, Economics, and Organization 6 (1990): 167-198.

30 William Lowry and Scott Krummenacher, "Coalitions and Conservation: Conditional Impacts of Coalitions on Ballot Measures for Open Space," Review of Policy Research 34, no. 3 (2017): 357-358.

31 Litman, Digital Copyright, 90. 
32 Information Infrastructure Task Force, U.S. Department of Commerce, The National Information Infrastructure: Agenda for Action, 58 Fed. Reg. 49025-01, 1993 WL 365171 (1993).

з3 Lehman interview, March 15, 2019.

34 Pamela Samuelson, interview with Patricia Aufderheide, September 28, 2018.

35 Samuelson interview, September 28, 2018.

36 Pamela Samuelson, "The U.S. Digital Agenda at WIPO," Virginia Journal of International Law 37, no. 2 (1997): 369-439; Pamela Samuelson, "Copyright and Digital Libraries," Communications of the ACM 38, no. 4 (1995):15-ff; Pamela Samuelson, "The Copyright Grab," Wired, January 1, 1996, https://www.wired.com/1996/01/white-paper/ (accessed July 11, 2019).

37 Jerome Reichman and Pamela Samuelson, "Intellectual Property Rights in Data?" Vanderbilt Law Review 50, no. 51 (1997): 52-166.

38 Mark Davison, "Database Protection: Lessons from Europe, Congress, and WIPO," Case Western Reserve Law Review 57, no. 4 (2016): 829-54.

39 Davison, "Database Protection," 844.

40 National Research Council, Bits of Power.

${ }_{41}$ Peter Jaszi, interview with the authors, June 6, 2018.

42 Benjamin Kaplan, An Unhurried View of Copyright, Republished (and with Contributions from Friends) (Newark: LexisNexis Matthew Bender, 2005); Peter Jaszi, "On the Author Effect: Contemporary Copyright and Collective Creativity." In The Construction of Authorship: Textual Appropriation in Law and Literature, eds. Martha Woodmansee and Peter Jaszi (Durham, NC: Duke University Press, 1994).

43 Martha Woodmansee and Peter Jaszi, The Construction of Authorship: Textual Appropriation in Law and Literature. (Durham, NC: Duke University Press, 1994).

44 Jaszi interview, June 6, 2018.

45 Prue Adler, interview with Bryan Bello, August 20, 2018.

46 Adler interview, August 20, 2018.

47 "Sign Up - DFC Meeting. DFC Member Sign-in Sheet," 12 February 1998, folder 2, box 1, Digital Future Coalition Archive, Program on Information Justice and Intellectual Property, Washington College of Law, American University, Washington, DC. (Hereafter DFCA-PIJIP). 
48 Adler interview, August 20, 2018.

49 James Lardner, Fast Forward: Hollywood, the Japanese, and the Onslaught of the VCR, 1st ed. (New York: Norton, 1987).

50 Anonymous, interview with authors, October 2, 2018.

51 Svea Windwehr and Christoph Schmon, "Our EU Policy Principles: Interoperability," Electronic Frontier Foundation, June 18, 2020, https://www.eff.org/deeplinks/2020/06/our-eu-policy-principles-interoperability.

52 Sega Enterprises Ltd. v. Accolade, Inc., 977 F.2d 1510 (9th Cir. 1992).

53 Jonathan Band, interview with authors, June 22, 2018.

54 Band interview, June 22, 2018; Schwartz and Greenstein interview, August 28, 2018.

55 Curtis Karnow, "Indirect Liability on the Internet and the Loss of Control" (INET 1999 Proceedings), Internet Society, 1999, Internet Archive, https://web.archive.org/web/20100219005230/http:/www.isoc.org/isoc/conferences/inet/ 99/proceedings/3e/3e_2.htm_(accessed July 1, 2020).

56 "Business Member Companies," Business Software Alliance, 1998, Internet Archive http://web.archive.org/web/19991012032644fw_/http://bsa.org/about/index.html (accessed July 1, 2020).

57 "The CIC Membership," Creative Incentive Coalition, 1998, Internet Archive, https://web.archive.org/web/19980110133715/http:/www.cic.org/memb.htm (accessed July 1,2020$)$.

58 See, Feist Publications, Inc. v. Rural Telephone Service Co., 499 U.S. 340 (1991).

59 Ed Black, email to authors, April 17, 2019.

60 Ed Black, interview with authors, January 7, 2019.

${ }_{61}$ Chris Byrne, "Statement of Chris Byrne Silicon Graphics, Inc. on behalf of the Information Technology Industry Council ('ITI'). Before the Senate Committee of Foreign Relations on the World Intellectual Property Organizations ('WIPO') Copyright Treaty and the WIPO Performances and Phonograms Treaty," 10 September 1998, folder 6, box 2, DFCA-PIJIP; Patricia Schroeder, Letter to Association of American Publishers, Inc. Constituents, 20 January 1998, folder 1, box 2, DFCA-PIJIP; Peter Jaszi, Letter to U.S. Senator Orin Hatch, Chairman of the Senate Judiciary Committee, 20 April 1998, folder 1, box 2, DFCA-PIJIP; Zoe Lofgren, Letter to U.S. House Representative Howard Coble, Chairman of the Subcommittee on Courts and Intellectual Property, Committee on the Judiciary, 22 April 1998, folder 1, box 2, DFCA-PIJIP. 
62 Byrne, 10 September 1998, DFCA-PIJIP; Schroeder to Association of American Publishers, 20 January 1998, DFCA-PIJIP; Jaszi to Orin Hatch, 20 April 1998, DFCAPIJIP; Lofgren to Howard Coble, 22 April 1998, DFCA-PIJIP.

63 Jaszi interview June 6, 2018; Schwartz and Greenstein interview, August 28, 2018. 64 Adler interview, August 20, 2018.

65 Anonymous interview, October 2, 2018.

66 Band interview, June 22, 2018.

67 "The Power of Coalitions: A Forum on Public Interest Intellectual Property Advocacy Honoring Prudence S. Adler," Washington College of Law, American University, April 17, 2019.

68 Love interview, June 29, 2018.

69 Schwartz and Greenstein interview, August 28, 2018.

70 Sens. Chuck Grassley and Paul Simon, Letter to Senator Mark Hatfield, 25 September, 1995, folder 1, box 2, DFCA-PIJIP.

71 S. Treaty Doc. No. 105-17 (1997); 2186 U.N.T.S. 121; 36 I.L.M. 65 (1997).

72 Seth Greenstein, Email to Select DFC members, 10 December 1996, folder 1, box 2, DFCA-PIJIP.

73 Greenstein to select DFC members, 10 December 1996, DFCA-PIJIP.

74 Greenstein to select DFC members, 10 December 1996, DCFA-PIJIP.

75 Adam Eisgrau, interview with authors, December 18, 2018.

76 Joel Jankowsky, interview with Patricia Aufderheide, February 5, 2019.

77 Eisgrau interview, December 19, 2018.

78 Peter Choy, Email to Christie Owens, 20 December 1996, folder 6, box 2, DFCAPIJIP.

79 National Research Council, Bits of Power, 134.

80 "WIPO Treaties Embrace Balance: Implementing Legislation Should Preserve It. Unidentified DFC boilerplate letter," 15 January 1997, folder 6, box 2, DFCA-PIJIP. 81 Lehman interview, March 15, 2018. 
82 Prue Adler, Email to the Digital Future Coalition, 12 November 1997, folder 7, box 1, DFCA-PIJIP.

83 Ruth Rodgers, interview with Patricia Aufderheide, February 7, 2019.

84 Rodgers interview, February 7, 2019.

85 "DFC - Our Current Issues, DFC webpage," 1 June 1998, folder 1, box 1, DFCAPIJIP.

86 Adler, Email to the Digital Future Coalition, 12 November 1997.

87 "DFC - Our Current Issues," June 1, 1998, DFCA-PIJIP.

88 Ruth Rodgers, Letter to Steve Castle, Congressional Quarterly, 21 January 1998, folder 3, box 1, Digital Future Coalition Archive, PIJIP; DFC, "Voters of the House of Representatives: Don't Miss the Thousands of Wake-up Calls Like These"

(Advertisement in Congressional Quarterly), ca. 1998, folder 3, box 1, DFCA-PIJIP.

89 “DFC - Our Current Issues," 1 June 1998.

90 Adam Eisgrau, Email to Helen Brunner, 12 November 1997, folder 7, box 1, DFCAPIJIP.

91 Rodgers interview, February 7, 2019.

92 Herman, The Fight over Digital Rights, 39.

93 Schroeder to Association of American Publishers Inc. Constituents, 20 January 1998, DFCA-PIJIP.

94 Jeri Clausing, "Entering the Net Copyright Debate, Johnny Cash," The New York Times, September 18, 1997,

http://movies2.nytimes.com/library/cyber/week/091897copyright (accessed July 11, 2019).

95 Schwartz and Greenstein interview, August 28, 2018.

96 "Creative Incentive Coalition - Introduction. CIC webpage," 12 February 1998, folder 2, box 1, DCFA-PIJIP.

97 Lehman interview, March 15, 2019.

${ }_{98} \mathrm{CIC}$, "Voters of the House of Representatives: Don't Miss the Thousands of Wake-up Calls Like These" (Advertisement in Congressional Quarterly), ca. 1998, folder 7, box 1, Digital Future Coalition Archive, PIJIP; CIC, "Voters of the House of Representatives: Don't Miss the Thousands of Wake-up Calls Like These" (Advertisement), ca. 1998, 
DFCA-PIJIP; CIC, "Stealing is : a) wrong" (Advertisement in Congressional Quarterly, ca. 1998, folder 3, box 1, DCFA-PIJIP.

99 Tarleton Gillespie, "Characterizing Copyright in the Classroom: The Cultural Work of Antipiracy Campaigns," Communication, Culture and Critique 2, no. 3 (2009): 274-318.

100 Anonymous interview, March 15, 2019.

101 "The Power of Coalitions: A Forum on Public Interest Intellectual Property Advocacy Honoring Prudence S. Adler", Washington College of Law, American University, April 17, 2019.

102 “The Power of Coalitions,” April 17, 2019.

103 Schwartz and Greenstein interview, August 28, 2018.

104 Skip Lockwood, Email to select DFC members, 26 March 1998, folder 1, box 2, DFCA-PIJIP.

105 Schroeder, Letter to Association of American Publishers, Inc. Constituents, 20 January 1998, folder 1, box 2, DFCA-PIJIP.

106 U.S. Congress, Senate, "Message From the President Of the United States Transmitting World Intellectual Property Organization Copyright Treaty...Signed by the United States On April 12, 1997," WIPO Contract Treaty (WCT) (1996) and WIPO Performances and Phonograms Treaty (WPPT) (1996), 105th Cong., 1st sess., 1997, Treaty Doc. 105-17, https://www.congress.gov/105/cdoc/tdoc17/CDOC-105tdoc17.pdf (accessed July 17, 2019).

107 Eisgrau interview, December 19, 2018.

108 Schwartz and Greenstein interview, August 28, 2018.

109 "DFC Membership Dues. Unidentified internal DFC financial record," ca. 2000, folder 1, box 1, DFCA-PIJIP.

110 Schwartz and Greenstein interview, August 28, 2018.

111 Schwartz and Greenstein interview, August 28, 2018.

112 "Cash Flow Report 4/30/96 Through 5/20/97. Unidentified Internal DFC Financial Record," 2 October 1997, folder 7, box 1, DFCA-PIJIP.

113 Schwartz and Greenstein interview, August 28, 2018.

114 Love interview, June 29, 2018.

115 Band interview, June 22, 2018. 
116 Lehman interview, March 15, 2019.

117 Jaszi interview, June 6, 2018; Eisgrau interview, December 19, 2018.

118 Eisgrau interview, December 19, 2018.

119 Jerome Reichman and Paul Uhlir, "Database Protection at the Crossroads: Recent Developments and Their Impact on Science and Technology," Berkeley Technology Law Journal 14, no. 793 (1999): 802, 803.

120 Reichman and Uhlir, "Database Protection at the Crossroads," 822.

121 Davison, "Database Protection," 844, 845, 853.

122 Davison, 844, 845, 853.

123 Bruce Lehman, message to author, March 15, 2019.

124 Davison, "Database Protection," 829.

125 Davison, 829.

126 Davison, 852, 853.

127 Gillespie, Wired Shut, 183.

128 Litman, Digital Copyright, 76.

129 Patricia Aufderheide, Aram Sinnreich, and Joseph Graf, "The Limits of the Limits of the Law: How Useable Are DMCA Anticircumvention Exceptions?" International Journal of Communication 12, no. 1 (2018): 4353-4372.

130 "Lumen Database," https://www.lumendatabase.org/ (accessed June 29, 2020).

${ }_{131}$ Patricia Aufderheide and Peter Jaszi, Reclaiming Fair Use: How to Put Balance Back in Copyright, 2nd ed. (Chicago; London: The University of Chicago Press, 2018), 84-85.

132 Aufderheide and Jaszi, Reclaiming Fair Use, 43-55.

133 Unlocking Consumer Choice and Wireless Competition Act, U.S. Code $17 \S 1201$ (2014); Brian Fung, "What a New Law about Cellphone Unlocking Has to Do with Coffee, Cars and Consumer Freedom," Washington Post, July 28, 2014, https://www.washingtonpost.com/news/the-switch/wp/2014/07/28/what-a-new-lawabout-cell-phone-unlocking-has-to-do-with-coffee-cars-and-consumer-freedom/ (accessed July 20, 2019); Kyle Wein, message to author, May 13, 2019.

134 Steve Metalitz, message to author, December 17, 2018. 
135 See table 1 notes $2-9$.

${ }_{136}$ Gabriel J. Michael, "Politics and Rulemaking at the Copyright Office," Journal of Information Technology \& Politics 11, no. 1 (January 2, 2014): 70-77.

137 Michael efficiently summarizes the exemption process: "The Copyright Office first issues a Notice of Inquiry, before any specific rules are being considered. Comments submitted during this period are 'initial' comments. After initial comments have been received, the office issues a Notice of Proposed Rulemaking, specifying proposed rules and soliciting comments on those rules. Comments submitted during this period are designated 'reply' comments, as they often explicitly position themselves in support or opposition to initial comments. Public hearings are held after both comment periods have ended, and eventually, the Copyright Office issues its final decision on rules." See Gabriel J. Michael, "Politics and Rulemaking at the Copyright Office," Journal of Information Technology \& Politics 11, no. 1 (January 2, 2014): 64-81. https://doi.org/10.1080/19331681.2013.872073. The process is explained directly by the Library of Congress in each exemption ruling, posted in the Federal Register. See, U.S. Copyright Office, "Exemption to Prohibition on Circumvention of Copyright Protection Systems for Access Control Technologies," Federal Register 83, no. 208 (October 26, 2018): 54010-54031.

138 U.S. Copyright Office, "Exemption to Prohibition on Circumvention of Copyright Protection Systems for Access Control Technologies," Federal Register 65, no. 209 (October 27, 2000): 64556-64574.

139 U.S. Copyright Office, "Exemption to Prohibition on Circumvention of Copyright Protection Systems for Access Control Technologies," Federal Register 68, no. 211 (October 31, 2003): 62011-62018.

140 U.S. Copyright Office, "Exemption to Prohibition on Circumvention of Copyright Protection Systems for Access Control Technologies," Federal Register 71, no. 227 (November 27, 2006): 68472-68480.

141 U.S. Copyright Office, "Exemption to Prohibition on Circumvention of Copyright Protection Systems for Access Control Technologies," Federal Register 75, no. 143 (July 27, 2010): 43825-43839.

142 U.S. Copyright Office, "Exemption to Prohibition on Circumvention of Copyright Protection Systems for Access Control Technologies," Federal Register 77, no. 208 (October 26, 2012): 65260-65279.

143 U.S. Copyright Office, "Exemption to Prohibition on Circumvention of Copyright Protection Systems for Access Control Technologies," Federal Register 80, no. 208 (October 28, 2015): 65944-65964.

144 U.S. Copyright Office, "Exemption to Prohibition on Circumvention of Copyright Protection Systems for Access Control Technologies," Federal Register 83, no. 208 (October 26, 2018): 54010-54031. 
145 In a given rulemaking process, the body of public comments produced reflect heterogenous forms of participation and indicate different experiences with $\S 1201$ of the DMCA. Comments may be coordinated and express unified support for an exemption among a well-organized group of commonly concerned parties. Participation flashpoints may emerge as changing social and economic norms generate new conflicts of interest. Mirror exemptions may be proposed by commenting parties operating independently and potentially unaware of one another. Such activity may signal a future flashpoint. Comments may also be novel with individual parties recommending unique exemptions that are not echoed by others. Finally, comments may be illegible in the sense that what is communicated does not meet the submission standards enforced by the Library of Congress. In summary, one cannot cleanly distinguish how many unique exemptions are proposed through the commenting process and thus produce a clean metric around the efficacy of public participation through the DMCA's triennial rulemaking process. It can be said that, so far, public participation modifies the power of $\$ 1201$ every rulemaking. These observations are derived directly from the rulemaking materials archived online by the Copyright Office for each rulemaking. See https://www.copyright.gov/1201/. See also the "final rule" entered in the Federal Register for each hearing, notes $2-8$.

146 Comments supporting a right-to-repair exemption for consumer electronics accounts for this outlier. Not an aberration though; the swell of participation was strategically coordinated by the advocacy group iFixit and the Electronic Frontier Foundation through a campaign they launched through Reddit. See Julia Bluff, "We Sent 40,000 Comments Demanding Reform to the Copyright Office," iFixit, February 10, 2015. https://www.ifixit.com/News/copyright-office.

147 Michael, "Politics and Rulemaking at the Copyright Office," 67. As Michael explains, comments submitted following the initial open comment phase "are designated 'reply' comments, as they often explicitly position themselves in support or opposition to initial comments."

148 Rules constitute new exemptions. Exemptions can't be cleanly counted from year-toyear or as a sum total registered at the end of each rulemaking. This is because exemptions are sometimes combined and expanded and thus do not purely constitute a renewal. By our count, renewals have been denied just three time - once in the 2006 hearing concerning website "filtering software applications" previously exempted in 2000 and renewed in 2003; twice in the 2010 hearing concerning a proprietary digital recording medium (exempted 2006) and library audiovisual media (exempted 2006) that would later be recovered through an expansion. See notes 2-6.

149 See note above

150 See note 12

151 Love interview, June 29, 2018; Eisgrau interview, December 18, 2018; Sarah

Deutsch, interview with the authors, May 9, 2019.

152 Jaszi interview, June 6, 2018; Deutsch, message to author, May 9, 2019. 
153 Jaszi interview, June 6, 2018.

154 Anonymous interview, September 29, 2018.

155 Annemarie Bridy, "Copyright Policymaking as Procedural Democratic Process: A Discourse-Theoretic Perspective on ACTA, SOPA, and PIPA," Cardozo Arts \& Entertainment Law Journal 30 (2012): 153-164.

156 Jonathan Band, "The SOPA-TPP Nexus," Joint PIJIP/TLS Research Paper Series, no. 2012-06 (Washington, D.C.: American University Washington College of Law, 2012), 48-52.

157 Band, "The SOPA-TPP Nexus," 43, 44.

158 Deutsch interview, May 9, 2019.

159 Black interview, January 7, 2019.

160 Jonathan Band, "The Power of Coalitions: A Forum on Public Interest Intellectual Property Advocacy Honoring Prudence S. Adler", Washington College of Law, American University, April 17, 2019.

161 "The Power of Coalitions: A Forum on Public Interest Intellectual Property Advocacy Honoring Prudence S. Adler", Washington College of Law, American University, April 17, 2019.

162 U.S. Copyright Office, Section 1201 Rulemaking: Seventh Triennial Proceeding to Determine Exemptions to the Prohibition on Circumvention - Recommendation of the Acting Register of Copyrights, by Karyn A. Temple (Washington, D.C.: U.S. Copyright Office, 2018): 342.

163 Kyle Wien, interview with authors, May 13, 2019.

164 Wien interview, May 13, 2019.

165 Wien interview, May 13, 2019.

166 Wien interview, May 13, 2019.

167 Makena Kelly, "Elizabeth Warren Comes out in Support of a National Right-to-Repair Law for Farm Equipment," The Verge, March 27, 2019, https://www.theverge.com/2019/3/27/18284011/elizabeth-warren-apple-right-to-repairjohn-deere-law-presidential-campaign-iowa; Nathan Proctor, "Right to Repair Is Now a National Issue," Wired, April 1, 2019, https://www.wired.com/story/right-to-repairelizabeth-warren-farmers/ (accessed February 2, 2020).

168 Wein, message to author, May 13, 2019. 
169 Rodgers interview, February 7, 2019.

170 Aufderheide and Jaszi, Reclaiming Fair Use, 84-85.

171 Alan Story, "'Balanced' Copyright: Not A Magic Solving Word," Intellectual Property Watch (blog), February 27, 2012, https://www.ip-watch.org/2012/02/27/'balanced'copyright-not-a-magic-solving-word/ (accessed June 30, 2019).

172 Story, "Balanced' Copyright."

173 David Bollier, Public Assets, Private Profits: Reclaiming the American Commons in an Age of Market Enclosure (Washington, D.C.: New America Foundation, 2001); David Bollier and Tim Watts, Saving the Information Commons: A Public Interest Agenda in Digital Media (Washington, DC: New America Foundation \& Public Knowledge, 2002); Boyle, The Public Domain.

174 "Public Interest Copyright Advocacy and Fair Use Education: 1995-2015," Program on Information Justice and Intellectual Property, American University Washington College of Law, http://www.pijip.org/copyrightadvocacy2015/ (accessed December 27, 2019).

175 Pamela Samuelson, message to author, September 28, 2018.

176 Joel Jankowsky, message to author, February 5, 2019.

177 OJ L 130, 17.5.2019, p. 92-125; 47 U.S.C. § 230; Communications Decency Act of 1996, (CDA), Pub. L. No. 104-104 (Tit. V), 110 Stat. 133; United States Copyright Office, Section 512 of Title 17: A Report on the Register of Copyrights (Washington, D.C.: U.S. Copyright Office, 2020) https://www.copyright.gov/policy/section512/ (accessed July 1, 2020).

178 "The Power of Coalitions: A Forum on Public Interest Intellectual Property Advocacy Honoring Prudence S. Adler," Washington College of Law, American University, April 17, 2019. 
DFC Membership 1996 - 98 (the DMCA years) 1

\begin{tabular}{|c|c|c|c|c|c|}
\hline $\operatorname{Org}_{2}$ & & Size4 & Reps5 & $\overline{Y_{6}}$ & Description7 \\
\hline $\begin{array}{l}\text { Alliance for Public } \\
\text { and Technology }\end{array}$ & $\mathrm{n}$ & 300 & Ruth Holder & 96 & $\begin{array}{l}\text { "To foster broad access to affordable, usable information and } \\
\text { communication services and technology." }\end{array}$ \\
\hline $\begin{array}{l}\text { American } \\
\text { Association of Law } \\
\text { Libraries }\end{array}$ & $\mathrm{n}$ & 4,800 & $\begin{array}{l}\text { Robert Oakley, } \\
\text { Mary Alice Baish }\end{array}$ & 96 & $\begin{array}{l}\text { "Provides leadership in the field of legal information, to foster } \\
\text { professional growth of law librarians and to develop the } \\
\text { profession of law librarianship." }\end{array}$ \\
\hline $\begin{array}{l}\text { American } \\
\text { Committee for } \\
\text { Interoperable } \\
\text { Systems }\end{array}$ & $\mathrm{t}$ & 30 & $\begin{array}{l}\text { Peter Choy, } \\
\text { Christie Owens, } \\
\text { Jon Band, Tom } \\
\text { Gan, Lowell } \\
\text { Sachs }\end{array}$ & 96 & $\begin{array}{l}\text { "Advocates IP policies that carefully balance strong protection } \\
\text { and incentives for motivation with the public interest goals of } \\
\text { interoperability, open systems and fair competition." }\end{array}$ \\
\hline $\begin{array}{l}\text { American Council } \\
\text { of Learned } \\
\text { Societies }\end{array}$ & $\mathrm{n}$ & 51 & Douglas Bennet & 96 & $\begin{array}{l}\text { "Supports humanistic research efforts and helps meet the present } \\
\text { and future needs of humanistic scholarship." }\end{array}$ \\
\hline $\begin{array}{l}\text { American Historical } \\
\text { Association }\end{array}$ & & 15,000 & Bonnie Hedges & 96 & $\begin{array}{l}\text { "The promotion of historical studies, the preservation of } \\
\text { historical documents and the dissemination of research." }\end{array}$ \\
\hline $\begin{array}{l}\text { American Library } \\
\text { Association }\end{array}$ & $\mathrm{n}$ & 56,444 & Adam Eisgrau & 96 & $\begin{array}{l}\text { "Provide leadership for the development, promotion, and } \\
\text { improvement of library and information services." }\end{array}$ \\
\hline $\begin{array}{l}\text { Art Libraries } \\
\text { Society of North } \\
\text { America }\end{array}$ & $\mathrm{n}$ & 1,500 & Marylyn Snow & 96 & $\begin{array}{l}\text { "Includes architecture and art librarians, visual resources } \\
\text { professionals, artists, curators, educators, publishers, and others } \\
\text { interested in visual arts information." }\end{array}$ \\
\hline $\begin{array}{l}\text { Association of } \\
\text { American } \\
\text { Geographers }\end{array}$ & $\mathrm{n}$ & N/A & Ron Abler & 96 & $\begin{array}{l}\text { "Advances professional studies in geography and encourages the } \\
\text { application of geographic research in education, government, } \\
\text { and business." }\end{array}$ \\
\hline $\begin{array}{l}\text { Association of } \\
\text { Research Libraries }\end{array}$ & $\mathrm{n}$ & 121 & Prue Adler & 96 & $\begin{array}{l}\text { "To influence forces affecting the future of research libraries in } \\
\text { the process of scholarly communication." }\end{array}$ \\
\hline $\begin{array}{l}\text { Committee of } \\
\text { Concerned } \\
\text { Intellectual } \\
\text { Property Educators }\end{array}$ & $\mathrm{n}$ & N/A & Peter Jaszi & 96 & N/A \\
\hline $\begin{array}{l}\text { Computer \& } \\
\text { Communication } \\
\text { Industry } \\
\text { Association } \\
\end{array}$ & $\mathrm{t}$ & 25 & Gregory Gorman & 96 & $\begin{array}{l}\text { "Represents a broad cross-section of the computer and } \\
\text { telecommunication industry." }\end{array}$ \\
\hline $\begin{array}{l}\text { Conference on } \\
\text { College } \\
\text { Composition and } \\
\text { Communication }\end{array}$ & $\mathrm{n}$ & 7,500 & $\begin{array}{l}\text { Andrea Lunsford, } \\
\text { Jim Porter }\end{array}$ & 96 & $\begin{array}{l}\text { "Actively concerned with the teaching of composition in } \\
\text { colleges and universities." }\end{array}$ \\
\hline $\begin{array}{l}\text { Consortium of } \\
\text { Social Science } \\
\text { Associations }\end{array}$ & $\mathrm{n}$ & 90 & Howard Silver & 96 & "Advocacy organization for the social and behavioral sciences." \\
\hline $\begin{array}{l}\text { Consumer } \\
\text { Federation of } \\
\text { America }\end{array}$ & $\mathrm{n}$ & 240 & Bradley Stillman & 96 & $\begin{array}{l}\text { "Advances the consumer interest through advocacy and } \\
\text { education." }\end{array}$ \\
\hline $\begin{array}{l}\text { Consumer Project } \\
\text { on Technology }\end{array}$ & $\mathrm{n}$ & N/A & Jamie Love & 96 & $\begin{array}{l}\text { "Investigate consumer issues presented by new technologies, } \\
\text { including information technologies." }\end{array}$ \\
\hline
\end{tabular}




\begin{tabular}{|c|c|c|c|c|c|}
\hline $\begin{array}{l}\text { Electronic Frontier } \\
\text { Foundation }\end{array}$ & $\mathrm{n}$ & N/A & Lori Fena & 96 & $\begin{array}{l}\text { "Ensure that civil liberties are protected as new communications } \\
\text { technologies emerge." }\end{array}$ \\
\hline $\begin{array}{l}\text { Electronic Privacy } \\
\text { Information Center }\end{array}$ & $\mathrm{n}$ & N/A & Marc Rotenberg & 96 & $\begin{array}{l}\text { "Focus public attention on emerging civil liberties issues } \\
\text { relating to the National Information Infrastructure." }\end{array}$ \\
\hline $\begin{array}{l}\text { Home Recording } \\
\text { Rights Coalition }\end{array}$ & $\mathrm{t}$ & N/A & $\begin{array}{l}\text { Seth Greenstein, } \\
\text { Bob Schwartz, } \\
\text { Ruth Rodgers, } \\
\text { Jeff Turner }\end{array}$ & 96 & $\begin{array}{l}\text { "Dedicated to preserving the right to purchase and use home } \\
\text { audio and video recording products for noncommercial } \\
\text { purposes." }\end{array}$ \\
\hline $\begin{array}{l}\text { Medical Library } \\
\text { Association }\end{array}$ & $\bar{n}$ & 5,000 & Mary Langman & 96 & "To serve the needs of health information specialists." \\
\hline $\begin{array}{l}\text { Modern Language } \\
\text { Association }\end{array}$ & $\bar{n}$ & 31,700 & Phyllis Franklin & 96 & $\begin{array}{l}\text { "Promotes study, criticism, and research in the modern } \\
\text { languages and their literatures." }\end{array}$ \\
\hline $\begin{array}{l}\text { National Council of } \\
\text { Teachers of English }\end{array}$ & & 100,000 & Patti Stock & 96 & $\begin{array}{l}\text { "Devoted to improving the teaching of English and the } \\
\text { language arts at all levels of education." }\end{array}$ \\
\hline $\begin{array}{l}\text { National Education } \\
\text { Association }\end{array}$ & $\bar{n}$ & $2,200,000$ & Barbara Yentzner & 96 & "Committed to advancing the cause of public education." \\
\hline $\begin{array}{l}\text { National } \\
\text { Humanities } \\
\text { Alliance }\end{array}$ & $\mathrm{n}$ & 750,000 & John Hammer & 96 & "Represents the humanities as a whole." \\
\hline $\begin{array}{l}\text { National School } \\
\text { Boards Association }\end{array}$ & $\overline{\mathrm{n}}$ & 95,000 & Gus Steinhilber & 96 & "Advocacy organization for public school governance." \\
\hline $\begin{array}{l}\text { National Writers } \\
\text { Union }\end{array}$ & $\mathrm{n}$ & 4,200 & Jonathan Tasini & 96 & "The largest union for freelance writers in the U.S." \\
\hline $\begin{array}{l}\text { People for the } \\
\text { American Way } \\
\text { Action Fund }\end{array}$ & $\mathrm{n}$ & 300,000 & Jill Lesser & $96^{*}$ & $\begin{array}{l}\text { "Through public education, litigation, and lobbying defends } \\
\text { Americans' fundamental liberties." }\end{array}$ \\
\hline $\begin{array}{l}\text { Special Libraries } \\
\text { Association }\end{array}$ & $\mathrm{n}$ & 14,000 & Lois Schoenbrun & 96 & $\begin{array}{l}\text { "Serving the information profession, including librarians, } \\
\text { information managers, brokers, and consultants." }\end{array}$ \\
\hline $\begin{array}{l}\text { American } \\
\text { Association of } \\
\text { Legal Publishers }\end{array}$ & $\overline{\mathrm{n}}$ & N/A & Eleanor Lewis & 97 & N/A \\
\hline $\begin{array}{l}\text { College Art } \\
\text { Association }\end{array}$ & $\mathrm{n}$ & 15,000 & Susan Ball & 97 & $\begin{array}{l}\text { Serve "those who by vocation or avocation are concerned about } \\
\text { and/or committed to the practice of art, teaching, and research of } \\
\text { and about the visual arts and humanities." }\end{array}$ \\
\hline $\begin{array}{l}\text { Computer } \\
\text { Professionals for } \\
\text { Social } \\
\text { Responsibility } \\
\end{array}$ & $\mathrm{n}$ & N/A & $\begin{array}{l}\text { Karen Coyle, Paul } \\
\text { Hyland }\end{array}$ & & $\begin{array}{l}\text { "Influence decisions regarding the development and use of } \\
\text { computers... provide the public and policymakers with } \\
\text { assessments of the power and limitations of computers." }\end{array}$ \\
\hline $\begin{array}{l}\text { Consortium for } \\
\text { School Networking }\end{array}$ & $\mathrm{n}$ & N/A & Sherry Ettleson & 97 & $\begin{array}{l}\text { "Further the development and use of telecommunications in K- } \\
12 \text { education." }\end{array}$ \\
\hline $\begin{array}{l}\text { International } \\
\text { Society for } \\
\text { Technology in } \\
\text { Education }\end{array}$ & $\mathrm{n}$ & 40,000 & $\begin{array}{l}\text { Sherry Ettleson, } \\
\text { Leslie Harris }\end{array}$ & 97 & $\begin{array}{l}\text { "Promotes appropriate uses of technology to support and } \\
\text { improve teaching and learning." }\end{array}$ \\
\hline $\begin{array}{l}\text { National } \\
\text { Association of } \\
\text { Independent } \\
\text { Schools } \\
\end{array}$ & $\mathrm{n}$ & 1,100 & $\begin{array}{l}\text { Jeff Burnet, } \\
\text { Chris Collins }\end{array}$ & 97 & $\begin{array}{l}\text { "Promoting high standards of educational quality and ethical } \\
\text { behavior." }\end{array}$ \\
\hline
\end{tabular}




\begin{tabular}{|c|c|c|c|c|c|}
\hline $\begin{array}{l}\text { National Initiative for a } \\
\text { Networked Cultural } \\
\text { Heritage }\end{array}$ & $\mathrm{n}$ & N/A & David Green & 97 & $\begin{array}{l}\text { "Formed to assure the fullest possible participation of the } \\
\text { cultural sector in the new digitally networked environment." }\end{array}$ \\
\hline $\begin{array}{l}\text { Society of American } \\
\text { Archivists }\end{array}$ & $\mathrm{n}$ & N/A & Susan Fox & 97 & $\begin{array}{l}\text { "Serves the needs of its members and provides leadership to } \\
\text { help ensure the identification, preservation, and use of the } \\
\text { nation's historical record." }\end{array}$ \\
\hline $\begin{array}{l}\text { Society for Cinema } \\
\text { Studies }\end{array}$ & $\mathrm{n}$ & N/A & Robert Kolker & 97 & $\begin{array}{l}\text { "A professional organization of college and university } \\
\text { educators, filmmakers, historians, critics, scholars, and others } \\
\text { devoted to the study of the moving image." }\end{array}$ \\
\hline $\begin{array}{l}\text { U.S. Catholic } \\
\text { Conference }\end{array}$ & $\mathrm{n}$ & N/A & $\begin{array}{l}\text { Pat Canan, } \\
\text { Katherine } \\
\text { Grincewich, } \\
\text { Michael Hill }\end{array}$ & 97 & N/A \\
\hline $\begin{array}{l}\text { U.S. Distance Learning } \\
\text { Association }\end{array}$ & $\mathrm{n}$ & N/A & Glenn Kessler & 97 & $\begin{array}{l}\text { "To promote the development and application of distance } \\
\text { learning for education and training." }\end{array}$ \\
\hline $\begin{array}{l}\text { Visual Resources } \\
\text { Association }\end{array}$ & $\mathrm{n}$ & N/A & Kathe Albrecht & 97 & $\begin{array}{l}\text { "To further research and education in the field of visual } \\
\text { resources and to promote a spirit of cooperation among the } \\
\text { members of the profession." }\end{array}$ \\
\hline $\begin{array}{l}\text { American Association of } \\
\text { School Administrators }\end{array}$ & $\mathrm{n}$ & 16,500 & N/A & 98 & $\begin{array}{l}\text { "Improving the condition of youth; Preparing schools and } \\
\text { school systems for the } 21 \text { st century; Connecting schools and } \\
\text { communities; Enhancing the quality of school leaders." }\end{array}$ \\
\hline $\begin{array}{l}\text { Association for } \\
\text { Computers and the } \\
\text { Humanities }\end{array}$ & $\mathrm{n}$ & N/A & N/A & 98 & $\begin{array}{l}\text { "Devoted to disseminating information about work in the field } \\
\text { of humanities computing and encouraging the development and } \\
\text { dissemination of software for research." }\end{array}$ \\
\hline $\begin{array}{l}\text { Chief Officers of State } \\
\text { Library Agencies }\end{array}$ & $\mathrm{n}$ & N/A & N/A & 98 & $\begin{array}{l}\text { "To further state library agency relationships with federal } \\
\text { government and national organizations and to initiate } \\
\text { cooperative action for the improvement of library services." }\end{array}$ \\
\hline $\begin{array}{l}\text { Music Library } \\
\text { Association }\end{array}$ & $\mathrm{n}$ & N/A & N/A & 98 & $\begin{array}{l}\text { "MLA provides a forum for study and action on issues that } \\
\text { affect music libraries and their users." }\end{array}$ \\
\hline
\end{tabular}

1 Membership is represented by organization name (Org), financial structure (S) with the categories of nonprofit (n) and trade group (t), the membership size of the organization (Size), representatives' names (Reps), the year the organization joined the DFC $(\mathrm{Y})$ with an asterisks $\left(^{*}\right)$ indicating one year membership, and a quoted summary of the organization's mission statement (Description). The roster is listed in alphabetical order by the year the organization joined the DFC starting in reverse chronological order.

2 Our record of organizations was compiled respectively from a 1998 prepared written testimony to congress (in which members were listed), two working rosters, and a sign in sheet. See Peter Jaszi, "Testimony of The Digital Future Coalition before The Senate Foreign Relations Committee," 10 September 1998, folder 6, box 2, Digital Future Coalition Archive, Program on Information Justice and Intellectual Property, Washington College of Law, American University, Washington, DC. (Hereafter DFCA-PIJIP); "Members and Contacts - DFC Meeting. DFC Roster," 2 October 1997, folder 8, box 2, DFCA-PIJIP; "Members and Contacts - DFC Meeting. DFC Roster," 12 February 1996, folder 8, box 2, DFCA-PIJIP; "Sign Up - DFC Meeting. DFC member sign-in sheet," 12 February 1996, folder 2, box 1, DFCA-PIJIP.

${ }_{3}$ Organizational details (structure, size, representatives, year joined, and description) were partially compiled from an archived print out of DFC's membership webpage ca. 1996. See "DFC - Organizational Biographies. DFC webpage," 5 February 1996, folder 8, box 2, DFCA-PIJIP. Descriptions of groups not listed in the aforementioned document that joined the DFC later were acquired via the Wayback Machine. We selected captures of these organizations' websites as close to the year they joined the DFC as possible to reflect accurate membership size and sense of mission.

Descriptions were excerpted from the "about us" page or equivalent.

4 “DFC - Organizational Biographies. DFC webpage," 5 February 1996, DFCA-PIJIP.

5 “DFC - Organizational Biographies. DFC webpage," 5 February 1996, DFCA-PIJIP. 
6 "DFC - Organizational Biographies. DFC webpage," 5 February 1996, DFCA-PIJIP. 7 “DFC - Organizational Biographies. DFC webpage," 5 February 1996, DFCA-PIJIP. 


\section{The First Digital Copyright Decade:}

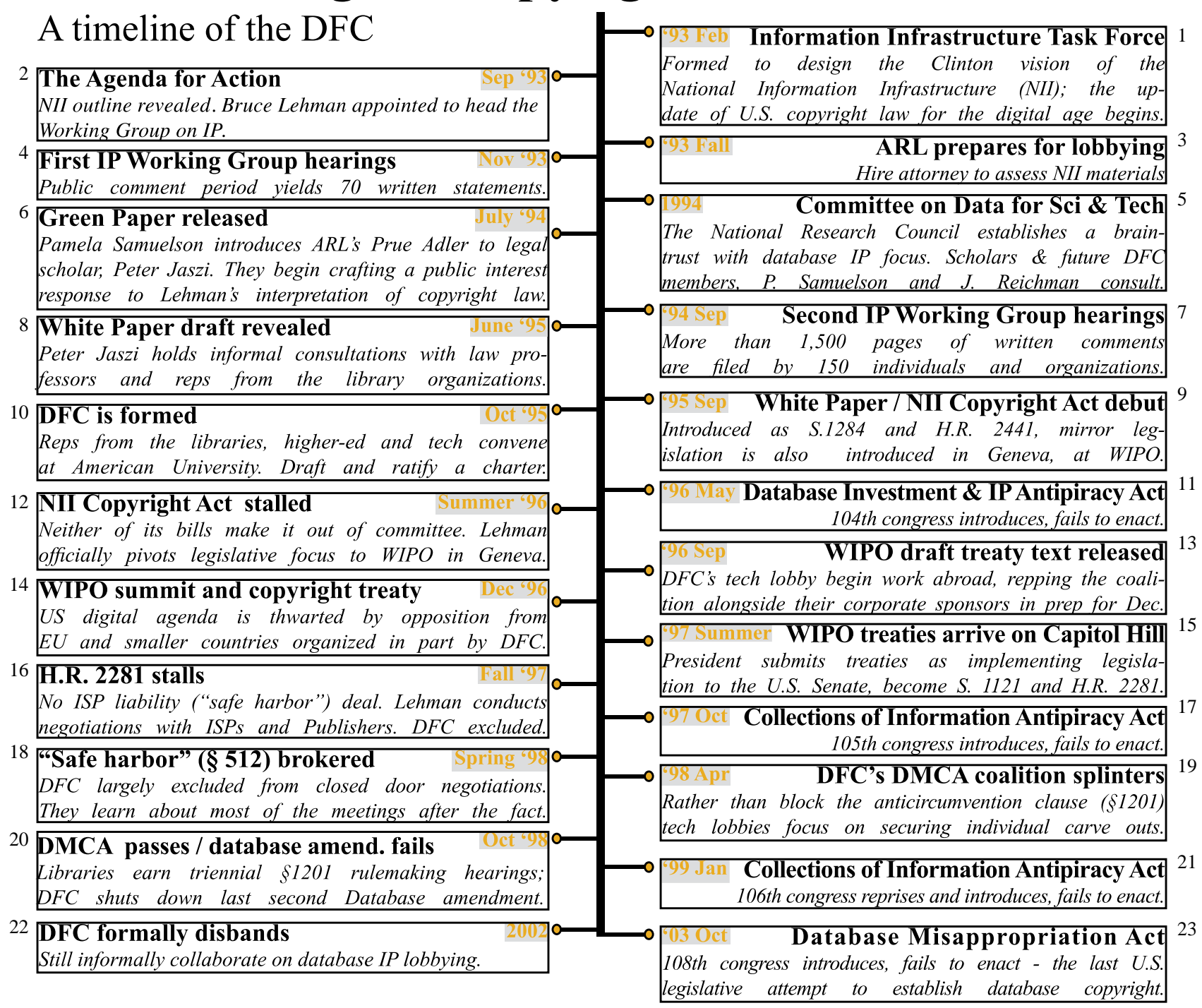

1. Jessica Litman, Digital Copyright: Protecting Intellectual Property on the Internet (New York: Prometheus Books, 2001), 90.

2. Information Infrastructure Task Force, U.S. Department of Commerce, The National Information Infrastructure: Agenda for Action, 58 Fed. Reg. 49025-01, 1993 WL 365171 (1993).

3. Prue Adler, interview with Bryan Bello, August 20, 2018.

4. Litman, Digital Copyright, 90.

5. National Research Council, Bits of Power: Issues in Global Access to Scientific Data. Washington, D.C.: National Academies Press, 1997. 
6. Information Infrastructure Task Force, Intellectual Property and the National Information Infrastructure: A Preliminary Draft of the Report of the Working Group on Intellectual Property Rights (1994).

7. Litman, Digital Copyright, 90.

8. Information Infrastructure Task Force, Intellectual Property and the National Information Infrastructure: The Report of the Working Group on Intellectual Property Rights (1995).

9. U.S. Congress, House, NII Copyright Protection Act of 1995, HR 2441 104th Cong., 1 st sess., September 29, 1995. https://www.congress.gov/bill/104th-congress/housebill/2441/text; U.S. Congress, Senate, NII Copyright Protection Act of 1995, S 1284 104th Cong., 1 st sess., September 28, 1995. https://www.congress.gov/bill/104thcongress/senate-bill/1284/text.

10. Jonathan Band, interview with authors, June 22, 2018; Peter Jaszi, interview with authors, June 6, 2018; Adler interview, August 20, 2018.

11.U.S. Congress, House, Database Investment and Intellectual Property Antipiracy Act of 1996, HR 3531 104th Cong., 2d sess., Introduced in House May 5, 1996.

https://www.congress.gov/bill/104th-congress/house-bill/3531/text.

12. Litman, Digital copyright, 128.

13. Pamela Samuelson, "The U.S. Digital Agenda at WIPO. (Symposium: Intellectual Property Law in the International Marketplace)", Virginia Journal of International Law, 37(2), (1997): 369-439.

\section{Samuelson, "WIPO."}

15. William Clinton, "Message from The President of the United States Transmitting World Intellectual Property Organization Copyright Treaty and the World Intellectual Property Organization Performances And Phonograms Treaty, Done At Geneva On December 20, 1996, And Signed By The United States On April 12, 1997". (July 28, 1997). Retrieved from https://www.congress.gov/105/cdoc/tdoc17/CDOC105tdoc17.pdf.

16. Litman, Digital copyright, 149.

17.U.S. Congress, House, Collections of Information Antipiracy Act, HR 2652, 105th Cong., 1st sess., October 09, 1997. https://www.congress.gov/bill/105thcongress/house-bill/2652/text.

18. Robert Schwartz and Seth Greenstein, interview with authors, August 28, 2018; Sarah Deutsch, interview with authors, May 9, 2019. 
19. Schwartz and Greenstein interview, August 28, 2018; Deutsch interview, May 9, 2019.

20. The Digital Millennium Copyright Act, Pub. L. No. 105-304 (1998); Jerome Reichman and Paul Uhlir. "Database Protection at the Crossroads: Recent Developments and Their Impact on Science and Technology." Berkeley Technology Law Journal 14, no. 793 (1999): 793-838.

21. U.S. Congress, House, Collections of Information Antipiracy Act, HR 354, 105th Cong., 1 st sess., January 19, 1999. https://www.congress.gov/bill/106thcongress/house-bill/354/text.

22. Band interview, June 22, 2018; Jaszi interview, June 6, 2018; Adler interview, August 20, 2018.

23. U.S. Congress, House, Database and Collections of Information Misappropriation Act, HR 3621, 108th Cong., 1st sess., October 03, 2003.

https://www.congress.gov/bill/106th-congress/house-bill/354/text. 
Appendix 3

\title{
List of Acronyms
}

\author{
AAP - Association of American Publishers \\ ACIS - American Committee for Interoperable Systems \\ AOL - America Online \\ ALA - American Library Association \\ $A R L$ - Association of Research Libraries \\ BSA - Business Software Association \\ CCIA - Computer and Communications Industry Association \\ CEA - Consumer Electronic Association \\ CIC - Creative Incentive Coalition \\ CODATA - Committee on Data for Science and Technology \\ DFC - Digital Future Coalition \\ DMCA - Digital Millennium Copyright Act \\ EC - European Community \\ EFF - Electronic Frontier Foundation \\ HRRC - Home Recordings Rights Coalition \\ IP - Intellectual Property \\ ISP - Internet Service Provider \\ IRB - Institutional Review Board \\ $\mathrm{MCl}$ - Microwave Communications, Inc., \\ MLA - Modern Language Association \\ MPAA - Motion Picture Association of America \\ OSP - Online Service Provider \\ OTA - Congressional Office of Technology Assessment \\ PK - Public Knowledge \\ NII - National Information Infrastructure \\ NRC - National Research Council \\ PIJIP - Program on Information Justice and Intellectual Property \\ RA - Repair Association \\ RAM - Random Access Memory \\ RIAA - Recording Industry Association of America \\ SOPA/PIPA - Stop Online Privacy Act/ Protect IP Act \\ TPM - Technological Protection Measures \\ USPTO - United States Patent and Trademark Office \\ WIPO - World Intellectual Property Organization
}

